The following manuscript entitled 'Effects of aseismic ridge subduction on geochemistry of frontal arc magmas' has been submitted for publication in Earth and Planetary Science Letters. Subsequent versions of this manuscript may differ more or less significantly from the present version. If accepted, the fnal version of this manuscript will be available via the 'Peer- reviewed Publication DOI' link on the right-hand side of this webpage. 


\section{Effects of aseismic ridge subduction on geochemistry of frontal arc magmas}

Massimo Chiaradia $^{1 *}$, Othmar Müntener², Bernardo Beate ${ }^{3}$

${ }^{1}$ Department of Earth Sciences, University of Geneva, Rue des Maraîchers 13, 1205 Geneva, Switzerland

${ }^{2}$ Institute of Earth Sciences, University of Lausanne, 1015 Lausanne, Switzerland

${ }^{3}$ Department of Geology, Escuela Politécnica Nacional, Quito, Ecuador

* corresponding author: Massimo.Chiaradia@unige.ch 


\begin{abstract}
Aseismic ridge subduction is considered to exert major controls on volcanic activity, formation of porphyry $\mathrm{Cu}-\mathrm{Au}$ deposits and the generation of juvenile Earth's crust. Yet, there are almost no studies that have addressed in a systematic way the effects of this process on the geochemistry of arc magmas. Here we explore the role of the subducted aseismic Carnegie ridge on modulating frontal arc magma chemistry in the Ecuadoriansouthernmost Colombian frontal arc. We show the occurrence of symmetric changes of several geochemical indices (Th, $\mathrm{Nd}, \mathrm{Sm}, \mathrm{Nb}, \mathrm{Th} / \mathrm{La}, \mathrm{Ba} / \mathrm{Th}$ ) and evolutionary paths $\left(\mathrm{Na}_{2} \mathrm{O}-\mathrm{SiO}_{2}\right.$ correlations) in frontal volcanic arc rocks with respect to the equatorial latitude and thus to the projection of the crest of the subducting Carnegie ridge at the frontal arc. We explore the systematic along-arc changes of these geochemical indices through geochemical modelling using a Monte Carlo approach, and conclude that the trends are primarily controlled by intracrustal processes. In particular we argue that magmatic systems associated with the central part of the Ecuadorian volcanic arc evolve, through hot zone type processes such as fractionation, partial melting and mixing, at average greater depths than those in the northern and southern sides. We speculate that this is due to a systematic latitudinal change in the crustal stress regime within the overriding plate induced by the subduction of the Carnegie ridge.
\end{abstract}

\title{
Introduction
}

Although a variant of the subduction of "normal" oceanic crust, subduction of topographic asperities (seamounts, oceanic plateaus, aseismic ridges) occurring upon the oceanic plate is not uncommon (e.g., present day Andean margin) and may have profound impacts on major geological processes. In fact, it is considered to affect the tectonic stress regime of the overriding plate and the subducted slab geometry (Espurt et al., 2008; Martinod et al., 2013) with 
consequences on volcanic activity (Gerya et al., 2009), the formation of ore deposits (Cooke et al., 2005; Rosenbaum et al., 2009; Chiaradia et al., 2009a) and that of the Earth's crust (Martin et al., 2014; Nair and Chacko, 2016).

Despite this there are very few studies (e.g., Ancellin et al., 2017) that have addressed in a more or less systematic way the effects of the subudction of oceanic plate topographic anomalies on arc magma geochemistry. Under this point of view the volcanic arc of Ecuador represents an ideal case study because the whole Ecuadorian arc sits above the aseismic Carnegie ridge (Figure 1), which has been subducted since at least 1 Ma (Lonsdale, 1978) or even longer (e.g., Spikings et al., 2001).

With the aim to investigate the effects of the subduction of an aseismic ridge on arc magma geochemistry, we discuss geochemical and isotopic data of $\sim 850$ volcanic rocks ( 86 of which from this study) from 21 volcanic centres of the frontal Quaternary Ecuadorian-Southern Colombian arc, situated between latitudes $1^{\circ} 30^{\prime} \mathrm{S}$ and $1^{\circ} 15^{\prime} \mathrm{N}$ (Fig. 1). These centres occur above the subducting Carnegie ridge at variable distances from the ridge crest projection on the frontal arc (Fig. 1). We have restricted our study to the frontal arc volcanoes to reduce disturbances associated with across-arc changing geochemistry due to decreasing slab inputs and degrees of partial melting of the mantle wedge away from the trench (Barragan et al., 1998; Chiaradia et al., 2009b, 2014a). For comparison we have also included Galeras volcano, which is the southernmost volcano of the single-chain Colombian arc, occurring north of the broad triplechain Ecuadorian arc (Fig. 1). On the other hand we have excluded the most frontal volcano of the Ecuadorian arc, Pilavo, which shows unique geochemical enrichments of all incompatible elements despite relatively primitive major 
element chemistry (Chiaradia et al., 2011). The data show the occurrence of symmetric changes of several geochemical indices with the center of symmetry situated around the equator (see also Ancellin et al., 2017). We apply geochemical modelling with a Monte Carlo approach to reconstruct the petrogenetic processes responsible for the symmetric changes in the geochemistry of frontal arc volcanoes and speculate about their link with the subduction of the Carnegie ridge.

\section{Geological setting}

The 12-20 Ma old oceanic crust subducting under Ecuador carries on top the 1319 km thick Carnegie ridge (Sallarès et al., 2005), produced by the Galapagos hot spot. The Carnegie ridge raises up to $>3000 \mathrm{~m}$ above the surrounding sea floor (Graindorge et al., 2004; Fig. 1). The thickness of the crust of the overriding plate in correspondence with the Ecuadorian frontal arc is about $50 \mathrm{~km}$ with no significant changes along the arc (Feininger and Seguin, 1983; Guillier et al., 2001). It consists from bottom upwards of a ca $20 \mathrm{~km}$ thick accreted Cretaceous oceanic plateau (Pallatanga) with an overlying oceanic arc (Upper Cretaceous Rio Cala arc), and a thick siliciclastic sequence (Campanian-Maastrichtian Yunguilla Formation and Maastrichtian-Eocene Angamarca Group) derived from the erosion of Proterozoic to Jurassic metamorphic and magmatic basement rocks of the Eastern Cordillera and of the Amazon craton (Vallejo et al., 2009) (Fig. 2). In the western part of the Western Cordillera the Angamarca Group makes locally lateral transition (Fig. 2) to the Paleocene-Eocene Macuchi Unit, a volcaniclastic unit of basaltic to dacitic composition intercalated with sedimentary rocks containing Proterozoic to Cambrian zircons from the South 
American Craton (Vallejo et al., 2009). Overall, the crustal section of the Western Cordillera shows a transition from Cretaceous mafic oceanic lithologies (Pallatanga terrane, Rio Cala island arc) in the deepest part to clastic lithologies with a variably old (Jurassic to Proterozoic) continental crust component in the mid and upper part (Fig. 2).

The volcanoes of the frontal arc of Ecuador sit on top or immediately adjacent to the suture zone between the accreted Pallatanga block and the continental margin (Vallejo et al., 2009) (Calacalí-Pujilí-Pallatanga, CPP, fault system: Fig. 1) or on top of the Chimbo-Toachi shear zone (Quilotoa; Fig. 1). Magmas could have exploited these structures to rise through the crust and form the frontal arc chain (Litherland and Aspden, 1992). Along the CPP suture zone, slivers of the deeper lithologies of the crustal section (i.e., Pallatanga, Rio Cala, Yunguilla) are exposed in some places.

\section{Materials and Methods}

This study uses a database of more than 760 rocks analysed by previous studies for major and trace elements and partly for radiogenic isotopes (Supplementary Dataset 1). We add to these 86 newly analysed rocks (major and trace elements as well as $\mathrm{Pb}, \mathrm{Sr}$ and $\mathrm{Nd}$ isotopes: dataset available under doi:10.6084/m9.figshare.7813940). Whole rock analyses of major, minor and trace elements of the present study were carried out at the Institute of Earth Sciences of the University of Lausanne (Switzerland) following the methods described in Chiaradia et al. (2014b), using XRF (major and minor elements) and LA-ICPMS on glass beads (trace elements). Radiogenic isotope ratios of $\mathrm{Sr}$ $\left({ }^{87} \mathrm{Sr} /{ }^{86} \mathrm{Sr}\right), \mathrm{Nd}\left({ }^{143} \mathrm{Nd} /{ }^{144} \mathrm{Nd}\right)$ and $\mathrm{Pb}\left({ }^{206} \mathrm{~Pb} /{ }^{204} \mathrm{~Pb},{ }^{207} \mathrm{~Pb} /{ }^{204} \mathrm{~Pb},{ }^{208} \mathrm{~Pb} /{ }^{204} \mathrm{~Pb}\right)$ were 
measured at the Department of Earth Sciences of the University of Geneva (Switzerland). Between 120 and $140 \mathrm{mg}$ of whole rock powder were dissolved during 7 days in Savillex® Teflon vials using $4 \mathrm{ml}$ of concentrated $\mathrm{HF}$ and $1 \mathrm{ml}$ of $\mathrm{HNO}_{3} 14 \mathrm{M}$, at a temperature of $140{ }^{\circ} \mathrm{C}$ and with the help of ultrasonication for 30 minutes twice a day. Subsequently, samples were dried and re-dissolved for 3 days (also with 30 minutes ultrasonication twice a day) in $3 \mathrm{ml}$ of $\mathrm{HNO}_{3} 14 \mathrm{M}$ and dried again. $\mathrm{Sr}, \mathrm{Nd}$ and $\mathrm{Pb}$ were then separated using cascade columns with $\mathrm{Sr}-$ Spec, TRU-Spec and Ln-Spec resins according to a protocol modified from Pin et al. (1994). Finally, the material was redissolved in $2 \% \mathrm{HNO}_{3}$ solutions and ratios were measured using a Thermo Neptune PLUS Multi-Collector ICP-MS in static mode. Ratios used to monitor internal fractionation were: ${ }^{88} \mathrm{Sr} /{ }^{86} \mathrm{Sr}=8.375209$ for the ${ }^{87} \mathrm{Sr} /{ }^{86} \mathrm{Sr}$ ratio, ${ }^{146} \mathrm{Nd} /{ }^{144} \mathrm{Nd}=0.7219$ for the ${ }^{143} \mathrm{Nd} /{ }^{144} \mathrm{Nd}$ ratio and ${ }^{203} \mathrm{Tl} /{ }^{205} \mathrm{Tl}=0.418922$ for the three $\mathrm{Pb}$ ratios $(\mathrm{a} \mathrm{Tl}$ standard was added to the solution). Used external standards were SRM987 $\left({ }^{87} \mathrm{Sr} /{ }^{86} \mathrm{Sr}=0.710248\right.$ : McArthur et al., 2001; $1 \sigma$ long-term external reproducibility: 10 ppm), JNdi-1 $\left({ }^{143} \mathrm{Nd} /{ }^{144} \mathrm{Nd}=0.512115:\right.$ Tanaka et al., $2000 ; 1 \sigma$ long-term external

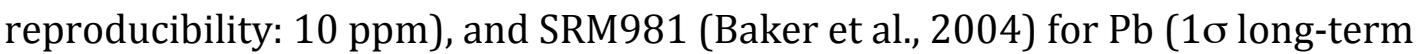
external reproducibility of $0.0048 \%$ for ${ }^{206} \mathrm{~Pb} /{ }^{204} \mathrm{~Pb}, 0.0049 \%$ for ${ }^{207} \mathrm{~Pb} /{ }^{204} \mathrm{~Pb}$ and $0.0062 \%$ for $\left.{ }^{208} \mathrm{~Pb} /{ }^{204} \mathrm{~Pb}\right) .{ }^{87} \mathrm{Sr} /{ }^{86} \mathrm{Sr},{ }^{143} \mathrm{Nd} /{ }^{144} \mathrm{Nd}$ and $\mathrm{Pb}$ isotope ratios were further corrected for external fractionation (due to a systematic difference between measured and accepted standard ratios) by a value of $-0.039 \%$, $+0.047 \%$ and $+0.5 \%$ amu respectively. Interferences at masses $84\left({ }^{84} \mathrm{Kr}\right), 86$ $\left({ }^{86} \mathrm{Kr}\right)$ and $87\left({ }^{87} \mathrm{Rb}\right)$ were corrected by monitoring ${ }^{83} \mathrm{Kr}$ and ${ }^{85} \mathrm{Rb},{ }^{144} \mathrm{Sm}$ interference on ${ }^{144} \mathrm{Nd}$ was monitored on the mass ${ }^{147} \mathrm{Sm}$ and corrected by using a ${ }^{144} \mathrm{Sm} /{ }^{147} \mathrm{Sm}$ value of 0.206700 and ${ }^{204} \mathrm{Hg}$ interference on ${ }^{204} \mathrm{~Pb}$ was corrected by 
monitoring ${ }^{202} \mathrm{Hg}$. Total procedural blanks were $<500 \mathrm{pg}$ for $\mathrm{Pb}$ and $<100 \mathrm{pg}$ for Sr and Nd which are insignificant compared to the amounts of these elements purified from the whole rock samples investigated.

\section{Results}

Rocks of all volcanic centres are porphyritic with phenocrysts of plagioclase, clino- \pm orthopyroxene, magnetite, \pm amphibole, \pm olivine, \pm biotite in variable proportions to the groundmass. They plot along the calc-alkaline range of basaltic andesite to rhyolites in the total alkali-silica diagram (Fig. 3a). Major elements versus $\mathrm{SiO}_{2}$ plots define volcano-distinct trends, which are negatively correlated for $\mathrm{TiO}_{2}, \mathrm{MgO}, \mathrm{Fe}_{2} \mathrm{O}_{3 \text { tot }}, \mathrm{CaO}$, and positively correlated for $\mathrm{Na}_{2} \mathrm{O}$ and $\mathrm{K}_{2} \mathrm{O}$ (Figs. 3 and $\mathrm{S} 1$ in Supplementary Material).

Volcano-distinct trends of increasing $\mathrm{Na}_{2} \mathrm{O}$ and Th with $\mathrm{SiO}_{2}$ (Fig. 3c-d) can also be identified. HREE and Y show an overall negative correlation with $\mathrm{SiO}_{2}$ (Fig. S1 in Supplementary Material) and distinct depletion trends with increasing $\mathrm{SiO}_{2}$ can be recognized within each volcano. Also Sr/Y and La/Yb display broad volcano-specific positive correlations with $\mathrm{SiO}_{2}$ (Fig. S1).

In the isotopic space ( $\mathrm{Sr}-\mathrm{Nd}, \mathrm{Sr}-\mathrm{Pb}, \mathrm{Pb}-\mathrm{Nd}, \mathrm{Pb}-\mathrm{Pb}$ ) each volcanic centre shows a clustered distribution with some intra-volcano variability that is lower than the overall inter-volcano variation (Fig. 4). Sr and $\mathrm{Nd}$ isotopes have relatively primitive compositions $\left(\varepsilon \mathrm{Nd}_{\mathrm{CHUR}}=+3\right.$ to $\left.+7 ;{ }^{87} \mathrm{Sr} /{ }^{86} \mathrm{Sr}=0.7037-0.7044\right)$. Several elements ( $\mathrm{Nd}, \mathrm{Sm}, \mathrm{Nb}, \mathrm{Ta}, \mathrm{Th}$ ) and, to some extent, also element ratios (Ba/Th), expressed as average values of the entire sample population of each volcano (Supplementary Dataset 2), display symmetric changes with respect to the equator (Fig. 5). 
Interestingly also the slopes of the $\mathrm{Na}_{2} \mathrm{O}-\mathrm{SiO}_{2}$ correlations for individual volcanoes (Figs. S2) display a broad symmetric distribution centred at latitude $0^{\circ}$ where slopes reach maximum values (Fig. 5f).

\section{Discussion}

The lifespans of frontal arc volcanic edifices of Ecuador range from few hundreds of thousands of years to about 1 Ma (e.g., Samaniego et al., 2010; Chiaradia et al., 2011; Beguelin et al., 2015). Averaging out the geochemical results of single volcanic edifices over these lifespans (Fig. 5) means loosing specific evolutionary stages within each volcano and rather obtaining time-integrated signatures. Because the lifetime of the investigated volcanoes coincides or is shorter than the duration of the Carnegie ridge subduction (see above) such approach is consistent with the aim of investigating the long-term, average effects of the Carnegie ridge subduction on frontal arc magma geochemistry. Additionally, the overall inter-volcano variability shown in Fig. 5 is higher than intra-volcano variability suggesting that, averaged over their lifetimes, geochemical signatures of frontal arc volcanoes of Ecuador are indeed distinct.

The results reported above highlight a symmetric latitudinal trend for several trace elements, trace element ratios, and element correlation slopes $\left(\mathrm{Na}_{2} \mathrm{O}-\mathrm{SiO}_{2}\right)$ with the centre of symmetry situated around the equator (Fig. 5). The overlap of the frontal Ecuadorian arc with the width of the Carnegie ridge and the fact that the inferred continuation of the Carnegie Ridge crest intersects the frontal arc at a latitude of about $0^{\circ}$ (Fig. 1) indicate that the Carnegie Ridge subduction could play a role in the symmetric distribution of geochemical signatures of the frontal 
arc volcanoes of Ecuador. The main question is whether such symmetric changes reflect mantle source processes or, alternatively, intracrustal processes. One could try to disentangle these two processes by considering only the geochemical signatures of the least evolved rocks of each volcano. This has been tested by previous studies based on a global compilation (Turner and Langmuir, 2015; Turner et al., 2016) and on Ecuador samples as well (Ancellin et al., 2017). Because there are not many primitive rocks in the Quaternary frontal arc of Ecuador (Fig. 3a) a threshold of Mg\#>50 can be chosen as a compromise to having an insight on relatively primitive rocks without removing too many samples for the statistical treatment of the population within each volcano (e.g., Ancellin et al., 2017). However, even by doing so, Ecuadorian rocks with Mg\#>50 have $\mathrm{SiO}_{2}$ and $\mathrm{MgO}$ ranging between 53-66 wt.\% and 8.5-2.0 wt.\%, respectively (Supplementary Dataset 1). All these rocks are far from being close to primary magmas and do not provide reliable insights on their mantle source. We do not exclude that latitudinal source controls may exist in frontal arc lavas of Ecuador but we think that they are not rigorously assessable with the available database.

\section{Geochemical trends within volcanoes}

Rocks from the volcanic edifices investigated range from basaltic andesite to rhyolite (Fig. 3a) and many individual volcanoes display a broad range of $\mathrm{SiO}_{2}$ variation (up to 12 wt.\%: Figs. S2). Previous studies have suggested that geochemical variability of Ecuadorian volcanoes is the result of fractional crystallization, mixing, partial melting and assimilation of the crust (Barragan et al., 1998; Bryant et al., 2006; Chiaradia et al., 2009b; Samaniego et al., 2010; Schiano et al., 2010; Chiaradia et al., 2014b; Beguelin et al., 2015). Schiano et al. 
(2010) have shown that geochemical trends of several Ecuadorian volcanoes can be explained by mixing between $\mathrm{SiO}_{2}$-poor and $\mathrm{SiO}_{2}$-rich melts but not by pure fractional crystallization, although they did not identify the nature of the $\mathrm{SiO}_{2}$ rich end-member.

Following the approach of Schiano et al. (2010), we have plotted incompatible elements that display clear symmetric changes around the equator (Th, $\mathrm{Nd}, \mathrm{Sm}$; Fig. 5) against a compatible element like V (Fig. 6). In the 1/V versus Th/V plot (Fig. 6a; see also similar plots for Nd, Sm: Fig. S3) each volcano defines linear trends with different slopes starting from the same high $\mathrm{V}$ and low $\mathrm{Th} / \mathrm{V}$ (low $\left.\mathrm{SiO}_{2}\right)$ end-member. Also in the accompanying plots of (Th, $\left.\mathrm{Nd}, \mathrm{Sm}\right)$ versus (Th, Nd, Sm)/V (Figs. 6b and S3), all volcanic edifices start from the same low (Th, Nd, $\mathrm{Sm} / \mathrm{V}$ end-member and plot along different curved trajectories. Th discriminates particularly well the different volcanoes, perhaps because it is the most incompatible element among the three.

We could successfully model the linear correlations in the $1 / \mathrm{V}$ vs. (Th, $\mathrm{Nd}, \mathrm{Sm}$ )/V and the curved correlations in the (Th, $\mathrm{Nd}, \mathrm{Sm}$ ) vs. (Th, Nd, Sm)/V spaces not only through simple mixing as Schiano et al. (2010), but also through an Assimilation-Fractional Crystallization (AFC) process (Fig. S4 and Supplementary Material for more details). Pure fractional crystallization is not able to reproduce the trends, as already discussed by Schiano et al. (2010). For both simple mixing and AFC processes the composition of the more primitive end-member was determined graphically by the common origin of the trends in the (Th, Nd, Sm)-V spaces (Figs. 6a-b and S3; Table S1) and we have used a Monte Carlo approach to characterize the evolved (high $\mathrm{SiO}_{2}$, high $\mathrm{Th} / \mathrm{V}$ and low V in Figs. 6a-b) end-member (melt or assimilant). For the AFC process we have 
allowed fractionation of the main mineral phases observed at frontal Ecuadorian volcanoes, i.e., plagioclase, clinopyroxene, amphibole, orthopyroxene plus minor amounts of apatite (up to $0.5 \%$ ) and magnetite (up to $2 \%$ ). Incidentally, the remarkably similar Th-Nd-Sm-V systematics of the more primitive end-member for all investigated edifices (convergence of all trends of the volcanoes to the same point in the Th-Nd-Sm-V spaces: Figs. 6a-b, S3) suggest that along-arc differences in average geochemical compositions of frontal volcanoes, at least for these elements, are due to changing compositions of the evolved end-member rather than to changes in the more primitive end-member.

The main outcome of our modelling is that, in the case of simple mixing, the $\mathrm{SiO}_{2}$ rich melts mixing with the $\mathrm{SiO}_{2}$-poor magma display a symmetrical increase of all incompatible elements around the equator (Figs. 6c-d, S3). Also in the case of AFC, modelling requires that the assimilant crust be characterized by increasing contents of the modelled incompatible elements away from the equator (Figs. 6cd, S3). Additionally, in the AFC process, the Nd and Sm trends are also controlled by changing proportions of plagioclase and amphibole fractionation with the lowest plagioclase/amphibole values at equatorial latitudes and progressively higher values at increasing distances from the equator (Fig. 6e, S3).

We have also modelled the symmetrically increasing $\mathrm{Nb}$ and Ta average concentrations of frontal volcanoes away from the equator (Fig. 5d) through mixing and AFC processes (Fig. 6f-h; Fig. S5). The very low Nb and Ta contents of near equatorial volcanoes and the progressive increase going away from the equator require variable fractionation of rutile in the AFC modelling (Fig. 6f: see also Tang et al., 2019) or, in the mixing model, very low $\mathrm{Nb}(2.2 \mathrm{ppm})$ and $\mathrm{Ta}$ $(0.18 \mathrm{ppm})$ contents in the $\mathrm{SiO}_{2}$-rich melts for the volcanoes near the equator, 
increasing to 7-8 ppm $\mathrm{Nb}$ and 0.5-0.6 ppm Ta for the volcanoes farthest away from the equator (Fig. 6g-h).

\section{Identification of the $\mathrm{SiO}_{2}$-rich melt}

The nature of the more primitive, $\mathrm{SiO}_{2}$-poor magmas is difficult to constrain rigorously due to the lack of primitive rocks in the volcanic edifices investigated. We can reasonably infer that they have evolved from a typical subductionrelated basalt, which could be similar along arc in terms of Th-Nd-Sm-V systematics. However, we do not exclude that differences exist in source processes and in geochemistry of the most primitive basalts along the Ecuadorian arc, but reiterate that the available database does not allow us to address this problem in a rigorous way.

In contrast we can say something more about the more evolved, $\mathrm{SiO}_{2}$-rich endmember. The data and modelling above indicate that the $\mathrm{SiO}_{2}$-poorer magmas (low $\mathrm{Th} / \mathrm{V}$ ) mix with $\mathrm{SiO}_{2}$-richer melts and/or assimilate crustal materials (AFC process) with variable latitudinal enrichment of incompatible elements (Figs. 3d, 5a-d). Based on previous studies on Ecuadorian arc magmatism (Bourdon et al., 2003; Bryant et al., 2006; Chiaradia et al., 2009b; Samaniego et al., 2010; Schiano et al., 2010; Chiaradia et al., 2014a-b; Ancellin et al., 2017), this can occur by a combination of three potential processes: (i) mixing of primitive, mantle-derived magmas with high-SiO ${ }_{2}$ slab melt components; (ii) mixing of primitive, mantlederived magmas with $\mathrm{SiO}_{2}$-rich partial melts of the crust; (iii) AFC of mantlederived parental magmas assimilating crustal rocks. The observation that volcanoes define diverging trends in diagrams of $\mathrm{SiO}_{2}$-incompatible elements (e.g., Th; Fig. 3d) and in the Th-Nd-Sm-V spaces (Figs. 6, S3) indicates that, if 
these trends are the result of mixing, the $\mathrm{SiO}_{2}$-rich melts cannot derive from different degrees of partial melting of the same source rock. Although we do not exclude the occurrence of slab melt-mantle wedge interaction beneath the Ecuadorian arc like under almost any arc (e.g., Plank et al., 2009), the above observation precludes that the symmetric changes of incompatible elements in the frontal arc of Ecuador are due to mixing of a primitive magma with variable degrees of partial melting of a broadly homogeneous basaltic slab. Differential contributions of sediment melts/fluids or changing sediment composition with latitude could potentially produce the systematic latitudinal changes (see also discussion below). Data on the chemical composition of sediments subducted at the Ecuadorian trench (currently lacking to our knowledge) would be needed to test more rigorously this hypothesis. On the other hand, we reiterate the contention that the lack of more primitive rocks in the Ecuadorian arc and the petrographic evidence of extensive crustal processes in the form of repeated mixing and recharge (e.g., Chiaradia et al., 2011, 2014b; Beguelin et al., 2015) make argumentation on mantle source processes ambiguous. Therefore, we turn to evaluate the possibility that the symmetric trends of incompatible elements are due to mixing of primitive magmas with partial melts of different crustal rocks and/or to AFC with assimilation of different crustal rocks. This approach is encouraged by the vertically changing litho-geochemical composition of the crust under the Western Cordillera of Ecuador (Fig. 2). Indeed, mixing with crustal melts and AFC are integrated aspects of the same overall process leading to hybrid magmas at lower to mid-crustal levels of arcs. Our separate modelling of these two processes is a simplification of a more complex evolution of arc magmas in which mantle-derived basaltic melts fractionate at 
different crustal levels, heat and eventually partially melt surrounding rocks then mixing with their partial melts to yield hybrid (mantle-derived plus crustal) melts (Annen et al., 2006).

Under the point of view of a mixing process, partial melts of Pallatanga rocks in the deepest part of the crustal section of the Western Cordillera of Ecuador would yield a $\mathrm{SiO}_{2}$-rich melt depleted in Th (Pallatanga rocks are depleted in Th $=0.2 \pm 0.08$ ppm; Fig. 2, Table 1). For instance, $20 \%$ partial melting of the Pallatanga crust would result in a $\mathrm{SiO}_{2}$-rich melt with only $1 \mathrm{ppm} \mathrm{Th}$, even assuming a $\mathrm{K}_{\mathrm{D}}$ of $\mathrm{Th}=0$. Mixing of such low $\mathrm{Th}, \mathrm{SiO}_{2}$-rich melt with mantlederived arc basalts (Th 1-2 ppm: Kelemen et al., 2005) could produce the Thpoor signature of near equatorial volcanoes (Fig. 5). On the other hand, partial melts of Pallatanga rocks would be too enriched (Table 1) to explain the low contents of $\mathrm{Nd}, \mathrm{Sm}$ and $\mathrm{Nb}$ of near equatorial volcanoes (Fig. 5) even for high partial melt fractions of $40 \%(\mathrm{Nb}>8 \mathrm{ppm}, \mathrm{Nd}>15 \mathrm{ppm}, \mathrm{Sm}>5 \mathrm{ppm})$ assuming $\mathrm{K}_{\mathrm{D}}$ 's of 0 for all these elements (Table 1 ). This suggests that, in the mixing model, $\mathrm{Nb}$, $\mathrm{Nd}$ and $\mathrm{Sm}$ must be depleted in the $\mathrm{SiO}_{2}$-rich melt, e.g., by retention in refractory minerals during partial melting of the Pallatanga rocks. Instead, AFC modelling returns median values of the assimilant for $\mathrm{Th}, \mathrm{Nd}, \mathrm{Sm}, \mathrm{Nb}$ and $\mathrm{Ta}$ that are perfectly compatible with Pallatanga values (Table 1), because it obviates to the above problem through higher amounts of rutile and amphibole fractionation in near equatorial volcanoes than in volcanoes farther north and south (Figs. 6e-f). For the volcanoes situated farthest away from the equator, AFC modelling requires contents of incompatible elements in the assimilant $(\mathrm{Th}=7-9 ; \mathrm{Nd}=15$ : Figs. 6c and S3) that are consistent with those of Eastern Cordillera source rocks of the Angamarca Group and Yunguilla Formation (Th 9.4 $\pm 6.7 \mathrm{ppm}, \mathrm{Nd}$ 
21.4 \pm 11.3 ppm: Fig. 2, Table 1), which form the upper half of the Western Cordillera crust (Fig. 2). Mixing requires Th contents in the $\mathrm{SiO}_{2}$-rich melt (7-11 ppm: Fig. 6c) that are even lower than those potentially contained in partial melts of Angamarca crustal rocks (e.g., 20\% melt of such rocks with an initial Th content of $7 \mathrm{ppm}$ would yield a melt with $>30 \mathrm{ppm}$ Th).

The detrital input of old Eastern Cordillera metamorphic material in the mid- to upper crustal sequences of the Western Cordillera could also explain the combined increase of crustal signatures of radiogenic isotopes $(\mathrm{Pb}, \mathrm{Nd})$ with incompatible elements in magmas farther away from the equator (Figs. 7a-b). The latter evolve at progressively shallower crustal levels assimilating rocks that display a measurable increase in crustal radiogenic isotopes from Pallatanga through Rio Cala to volcanic rocks of Macuchi and detrital sequences of the Angamarca Group (Table 1; Fig. 2). This scenario is consistent with the $\mathrm{Pb}$ isotope composition of Eastern Cordillera rocks (Fig. 4). Fig. 4 also shows that radiogenic isotope signatures of near equatorial volcanoes are consistent with assimilation of the Pallatanga oceanic plateau (forming the lower part of the crustal section of the Western Cordillera) and not only with the subducted Galapagos Islands material. The latter point was taken as an indicator of a contribution of slab melts from the Carnegie ridge (=Galapagos Islands composition) in some volcanoes like Pilavo and Imbabura (Ancellin et al., 2017), but indeed $\mathrm{Pb}$ isotopes are not conclusive in this sense (Fig. 4).

\section{Modelling of major element geochemistry}

In order to test the reliability of the above model, based on trace elements, we have also modelled for each volcano the combined linear trends in the $\mathrm{SiO}_{2}$ 
versus $\mathrm{Na}_{2} \mathrm{O}, \mathrm{MgO}, \mathrm{Al}_{2} \mathrm{O}_{3}$ and $\mathrm{CaO}$ spaces (e.g., Figs. 3, S1-2). These linear trends could be the result of mixing or AFC as discussed above for the trace elements, but are ultimately related to fractionation and/or partial melting processes involving different mineral phases in the fractionating mantle-derived primitive melt and in the partial melts of crustal rocks, which are then mingled or mixed in hot zones at different lower to mid-crustal levels. For the sake of simplicity, we have modelled the trends for each volcano in the $\mathrm{SiO}_{2}-\mathrm{MgO}-\mathrm{Na}_{2} \mathrm{O}-\mathrm{CaO}-\mathrm{Al}_{2} \mathrm{O}_{3}$ space, as they were the result of fractional crystallization-dominated processes of the main silicate minerals (plagioclase, amphibole, and clinopyroxene) observed in the rocks investigated, starting from the least evolved sample of each volcano (see Supplementary Material for details on modelling). Rather remarkably, the proportions of fractionating plagioclase to fractionating amphibole required by this modelling symmetrically increase with distance from the equator (Fig. 7c), both northward and southward, in agreement with modelling obtained using trace elements (see above). The two models also return similar plagioclase/amphibole ratios (Figs. 6e and 6c).

\section{Latitudinal changes in geochemistry: an intracrustal signal}

The above modelling results (Figs. 6 and 7c) are consistent with a hydrous magmatic evolution at average higher pressures near equatorial latitudes (where amphibole and rutile are more stable than plagioclase) than farther to the north or south (Fig. 8). Modelling results are also consistent with the requirement of assimilation by near equatorial magmas of incompatible element-poor Pallatanga rocks (and/or their partial melts: Table 1), which constitute the deepest part of the crustal section (Figs. 2, 7, 8). Northward and southward of 
the equator, magmas evolve at progressively lower pressures, where plagioclase fractionation becomes more important and assimilation/partial melting is affecting rocks with higher incompatible element contents and situated higher up in the crustal column (Figs. 2, 7, 8).

Additionally, the $\mathrm{Na}_{2} \mathrm{O}-\mathrm{SiO}_{2}$ slopes display significant correlations with $\mathrm{Th}, \mathrm{Ba} / \mathrm{Th}$ and Th/La average ratios of volcanic edifices (Figs. 7d-f), which are usually related to slab input. Because the $\mathrm{Na}_{2} \mathrm{O}-\mathrm{SiO}_{2}$ slopes are reasonably the result of intracrustal processes, such correlations suggest that symmetric changes of $\mathrm{Ba} / \mathrm{Th}$ and Th/La in Ecuadorian frontal arc volcanoes are also controlled somewhat by magmatic evolution in hot zone-type crustal processes (AFC + mixing). Such processes could have modulated the sediment slab signal, which usually controls the values of these ratios in primitive arc basalts (e.g., Plank, 2005). In fact, the systematics of the $\mathrm{Na}_{2} \mathrm{O}-\mathrm{SiO}_{2}$ slopes versus $\mathrm{Ba} / \mathrm{Th}$ and $\mathrm{Th} / \mathrm{La}$ (Figs. 7e-f) indicate that volcanoes at the low end of the $\mathrm{Na}_{2} \mathrm{O}-\mathrm{SiO}_{2}$ slopes (i.e., those situated farthest away from the equator) can only be explained through assimilation of/mixing with mid-upper crustal lithologies of the crustal column (the only reservoir with high $\mathrm{Th} / \mathrm{La}$ and low $\mathrm{Ba} / \mathrm{Th}$ at the same time: Figs. 7e-f). In contrast, volcanoes on the high end of the $\mathrm{Na}_{2} \mathrm{O}-\mathrm{SiO}_{2}$ slopes have either a strong signature from subducted sediments (high $\mathrm{Ba} / \mathrm{Th}$ and low $\mathrm{Th} / \mathrm{La}$ ) and/or assimilate lower crustal Pallatanga rocks (low Th/La, high Ba/Th: Figs. 7e-f). This scenario is consistent with the above conclusions based on modelling in the Th-Nd-Sm-Nb-V spaces.

\section{Geodynamic significance and implications}


Our data suggest that melts stall and evolve at average greater depths at equatorial latitudes than farther to the north and south (Fig. 8). In the absence of significant changes in crustal thickness along the frontal arc section investigated, we infer that melt residence at average greater depth in coincidence with equatorial latitudes could be due to the impingement at the trench of the topographic anomaly represented by the buoyant Carnegie ridge (Fig. 8). By effect of this process, the overriding plate crust and the CPP suture zone could be submitted to a higher compressional stress in the equatorial zone due to the increased coupling between ridge crest subduction and overriding plate (e.g., Espurt et al., 2008; Martinod et al., 2013). This could cause a maximum slowing down of magma ascent through the crust in the equatorial region with effects rapidly decreasing away from the axis of the ridge, north and south of the equator. It is remarkable that such an effect is visible in a short volcanic segment ( $\sim 200 \mathrm{~km})$, which is overlapping the whole width of the Carnegie ridge (Figs. 1 and 7). If our hypothesis is correct, this would imply that the stress transmitted by the Carnegie ridge to the overriding plate is strongly correlated with the crested topography of the subducting ridge (Figs. 1 and 7). To our knowledge, there are no quantitative data on the stress within the overriding plate in Ecuador at a resolution scale that allows testing this hypothesis within the arc segment here studied. However, data discussed in Spikings and Simpson (2014) show that, in the Eastern Cordillera of Ecuador, a significant change in the exhumation rate occurred at 15-13 Ma, as a result of Carnegie ridge subduction at that time, within less than $0^{\circ} 30^{\prime}$ of latitude $(\sim 55 \mathrm{~km})$, i.e., a spatial scale that is compatible with that of the observed geochemical changes in the Quaternary Ecuadorian frontal arc volcanoes. 
Based on the above results, we argue that a major effect of the subduction of the Carnegie aseismic ridge (and, possibly, of aseismic ridges in general) is to increase the average depth of crustal evolution of arc magmas by slowing down their ascent. In Ecuador, magmatic consolidation of mafic crust (Pallatanga oceanic plateau and overlying arcs), occurring through this process, leads to a juvenile dioritic-granodioritic continental crust with primitive isotope compositions and with geochemical signatures similar to those of Archean TTGs in Ecuador (Martin et al., 2014) albeit the processes of formation of Archean and modern rocks with such similar geochemical signatures are probably different (Smithies, 2000; Chiaradia et al., 2014b; Chiaradia, 2015). This process is also fundamental for the generation of large and long-lived lower crustal hydrous magmatic systems, which are the pre-requisite to form the largest porphyry copper deposits (Chiaradia and Caricchi, 2017) and can explain the relationship between aseismic ridge subduction and the generation of giant porphyry copper systems (Cooke et al., 2005; Rosenbaum et al., 2005; Chiaradia et al., 2009b).

\section{Acknowledgements}

We thank A. Ulianov (University of Lausanne) as well as F. Capponi and M. Senn (University of Geneva) for their precious help in the laboratory. This study was funded by the Swiss National Foundation (grant N. 200020_162415 to MC). 


\section{Figure captions}

Fig. 1:

Map view of the Quaternary volcanoes of Ecuador and alongarc section of the frontal arc. a. Geotectonic map of Ecuador showing the location of the frontal arc volcanoes investigated in this study (red). Also shown are the inferred continuation of the Carnegie ridge (Gutscher et al., 1999) and the inferred continuation of the Carnegie ridge crest (CGR) (Sage et al., 2006). Volcanoes: 1 = Galeras; 2 = Azufral; 3 = Cumbal; $4=$ Chiles; 5 = Cerro Negro de Mayasquer; 6 = Iguan; 7 = Yanaurcu; 8 = Chachimbiro; 9-10 = Cuicocha-Cotacachi; $11=$ Pululahua; 12 = Casitagua; 13 = Pichincha; $14=$ Atacazo; $15=$ Corazón; 16 = Almas Santas; 17 = Illiniza; 18 = Quilotoa; $19=$ Carihuairazo; 20 = Chimborazo.

Fig. 2: $\quad$ Composite section of the crust of the Western Cordillera of Ecuador (from Vallejo et al., 2009). Also reported are average values of incompatible element concentrations and $\mathrm{Pb}$ isotopic compositions in the crustal rocks (source data: Mamberti et al., 2003; Chiaradia, 2009; Chiaradia et al., 2004; Litherland et al., 1994).

Fig. 3: Compositions of frontal arc volcanic rocks of Ecuador (a) and variations of some major (b-c) and trace element (d) contents with $\mathrm{SiO} 2$. 
Fig. 4:

$\mathrm{Pb}, \mathrm{Nd}$, and $\mathrm{Sr}$ isotope plots of volcanic rocks from the investigated volcanoes (data are from this study, Ancellin et al., 2017 and the Georoc database: http://georoc.mpchmainz.gwdg.de/georoc/). The isotope fields of the Pallatanga oceanic plateau, Galapagos Islands (GIs), East Pacific Rise (EPR), and Eastern Cordillera are from Mamberti et al. (2003), White et al. (1993), and Chiaradia et al. (2004) respectively. The Pilavo and Imbabura fields are from Chiaradia et al. (2011) and Ancellin et al. (2017) respectively.

Fig. 5: Latitudinal variations of geochemical parameters of rocks expressed as average values of each volcano. Error bars represent $1 S D$ of the volcano population variability. In Fig. 5f, Cerro Negro and Corazon are greyed because the $\mathrm{Na}_{2} \mathrm{O}-\mathrm{SiO}_{2}$ regressions for these 2 volcanoes are based on only 4 samples.

Fig. 6: (a) 1/V-Th/V trends defined by the frontal arc volcanoes; (b) (a) Th-Th/V trends defined by the frontal arc volcanoes; (c-d) median values from Monte Carlo modeling of the Th and Sm contents of the assimilant (AFC model black) and of the mixed melt (mixing model grey) needed to explain the trends in the plots of Figs. 7a-b (see Supplementary Material); (e) changes in the ratio of fractionating plagioclase and 
amphibole (median values from Monte Carlo modeling) in the AFC model needed to explain the different trends defined by the volcanoes in the $1 / \mathrm{V}-\mathrm{Sm} / \mathrm{V}$ and $\mathrm{Sm}-\mathrm{Sm} / \mathrm{V}$ space (see Supplementary Material); (f) results of Monte Carlo modeling of an AFC process to explain the latitudinal variations of $\mathrm{Nb}$ and Ta contents of frontal arc volcanoes: slightly more than 1 wt.\% fractionation of rutile is required to explain the low $\mathrm{Nb}$ and Ta values of equatorial volcanoes (see Supplementary Material); (g) results of Monte Carlo modeling of a mixing process showing the required $\mathrm{Nb}$ contents of the $\mathrm{SiO}_{2}$-rich melt and their changes with latitude (see Supplementary Material). In Fig. 6c, d, e, Cerro Negro and Corazon have no color fillings to highlight the fact that the regressions for these 2 volcanoes are based on only 4 samples.

Fig. 7:

(a-b) Correlations of average values of radiogenic isotopes with average contents of incompatible elements in frontal arc volcanoes of Ecuador; (c) changes in the ratio of fractionating plagioclase and amphibole (median values from Monte Carlo modeling) needed to explain the different trends defined by the volcanoes in the $\mathrm{SiO}_{2}-\mathrm{Na}_{2} \mathrm{O}, \mathrm{SiO}_{2}-\mathrm{MgO}, \mathrm{SiO}_{2}-\mathrm{Al}_{2} \mathrm{O}_{3}, \mathrm{SiO}_{2}-$ CaO spaces (see Supplementary Material); (d-f) correlations between the $\mathrm{SiO}_{2}-\mathrm{Na}_{2} \mathrm{O}$ slopes defined by each volcano sample populations and their average $\mathrm{Th}, \mathrm{Ba} / \mathrm{Th}$ and $\mathrm{Th} / \mathrm{La}$ values. In Fig. 7d, e, f, Cerro Negro and Corazon are greyed to 
highlight the fact that the $\mathrm{Na}_{2} \mathrm{O}-\mathrm{SiO}_{2}$ regressions for these 2 volcanoes (Fig. S2) are based on only 4 samples. The Ba/Th and Th/La values of Eastern Cordillera and Pallatanga rocks are from Table 1 and those of hemipelagic and carbonated sediments are from Patino et al. (2000). $\mathrm{AB}=\operatorname{arc}$ basalt is the range of $\mathrm{Ba} / \mathrm{Th}$ and $\mathrm{Th} / \mathrm{La}$ values of oceanic and continental arc basalts from Kelemen et al. (2005).

Fig. 8: $\quad$ Cartoon showing the different along-arc evolution of magmatic reservoirs of the frontal arc volcanoes as suggested by geochemical and isotopic data. Near-equatorial volcanoes are derived from reservoirs mainly developing in the lowermost part of the crust which is composed of oceanictype rocks (Cretaceous Pallatanga plateau and Rio Cala island arc). With increasing distance from the equator magma reservoirs feeding the volcanoes develop at progressively shallower levels in a crust portion that is composed of detrital sequences with a dominant Proterozoic to Mesozoic crustal component derived from the erosion of the Eastern Cordillera and Amazon craton. 


\section{References}

Annen, C., Blundy, J. D., Sparks, R. S. J., 2006. The genesis of intermediate and silicic magmas in deep crustal hot zones. J. Pet. 47, 505-539.

Ancellin, M.-A., Samaniego, P., Vlastélic, I., Nauret, F., Gannoun, A., Hidalgo, S., 2017. Across-.. arc versus along. arc $\mathrm{Sr} \cdot-\mathrm{Nd}$-.-Pb isotope variations in the Ecuadorian volcanic arc. Geochemistry, Geophysics, Geosystems 18, doi:10.1002/2016GC006679.

Baker, J., Peate, D., Waight, T., Meyzen, C., 2004. Pb isotopic analysis of standards and samples using a $207 \mathrm{~Pb}-204 \mathrm{~Pb}$ double spike and thallium to correct for mass bias with a double--.focusing MC--.ICPMS. Chemical Geology 211, 275-303.

Barragan, R., Geist, D., Hall, M., Larsen, P., Kurz, M., 1998. Subduction controls on the compositions of lavas from the Ecuadorian Andes. Earth Planet. Sci. Lett. 154, 153166.

Beguelin, P., Chiaradia, M., Beate, B., Spikings, R.A., 2015. The Yanaurcu volcano (Western Cordillera, Ecuador): A field, petrographic, geochemical, isotopic and geochronological study. Lithos 218-219, 37-53.

Bourdon, E., Eissen, J. P., Gutscher, M. A., Monzier, M., Hall, M. L., Cotten, J., 2003. Magmatic response to early aseismic ridge subduction: the Ecuadorian margin case (South America). Earth Planet. Sci. Lett. 205, 123--138.

Bryant, J.A., Yogodzinski, G.M., Hall, M.L., Lewicki, J.L., Bailey, D.G., 2006. Geochemical constraints on the origin of volcanic rocks from the Andean northern volcanic zone, Ecuador. J. Pet. 47, 1147-1175.

Chiaradia, M., 2009. Adakite-like magmas from fractional crystallization and melting..assimilation of mafic lower crust (Eocene Macuchi arc, Western Cordillera, Ecuador). Chem. Geol. 265, 468-487.

Chiaradia, M., 2015. Crustal thickness control on Sr/Y signatures of recent arc magmas: an Earth scale perspective. Sci. Rep. 5, 8115.

Chiaradia, M., Caricchi, L., 2017. Stochastic modelling of deep magmatic controls on porphyry copper deposit endowment. Sci. Rep. 7, 44523. 
Chiaradia, M., Fontboté, L., Paladines, A., 2004. Metal sources in mineral deposits and crustal rocks of Ecuador (1 N-4 S): a lead isotope synthesis. Econ. Geol. 99, 1085-1106.

Chiaradia, M., Merino, D., Spikings, R., 2009a. Rapid transition to long.-lived deep crustal magmatic maturation and the formation of giant porphyry.-related mineralization (Yanacocha, Peru). Earth Planet. Sci. Lett. 288, 505-515.

Chiaradia, M., Müntener, O., Beate, B., Fontignie, D., 2009b. Adakite--like volcanism of Ecuador: lower crust magmatic evolution and recycling. Contrib. Min. Pet. 158, $563-588$.

Chiaradia, M., Müntener, O., Beate, B., 2011. Enriched basaltic andesites from mid."- crustal fractional crystallization, recharge, and assimilation (Pilavo volcano, Western Cordillera of Ecuador). J. Pet. 52, 1107-1141.

Chiaradia, M., Barnes, J.D., Cadet--Voisin, S., 2014a. Chlorine stable isotope variations across the Quaternary volcanic arc of Ecuador. Earth Planet. Sci. Lett. 396, 22-33.

Chiaradia, M., Müntener, O., Beate, B., 2014b. Quaternary Sanukitoid-like Andesites Generated by Intracrustal Processes (Chacana Caldera Complex, Ecuador): Implications for Archean Sanukitoids. J. Pet. 55, 769-802.

Cooke, D., Hollings, P., Walshe, J.L., 2005. Giant porphyry deposits: characteristics, distribution, and tectonic controls. Econ. Geol. 100, 801-818.

Espurt, N., Funiciello, F., Martinod, J., Guillaume, B., Regard, V., Faccenna, C., Brusset, S., 2008. Flat subduction dynamics and deformation of the South American plate: Insights from analog modeling. Tectonics 27, TC3011.

Feininger, T., Seguin, M.K., 1983. Bouguer gravity anomaly field and inferred crustal structure of continental Ecuador. Geology 11, 40-44.

Gerya, T. V., Fossati, D., Cantieni, C., Seward, D., 2009. Dynamic effects of aseismic ridge subduction: numerical modeling. Eur. J. Mineral. 21, 649-661.

Graindorge, D., Calahorrano, A., Charvis, P., Collot, J.Y., Bethoux, N., 2004. Deep structure of the Ecuador convergent margin and the Carnegie Ridge, possible consequences on great earthquakes recurrence interval. Geophysical Res Lett 31. doi:10.1029/2003GL018803. 
Guillier, B., Chatelain, J.L., Jaillard, E., Yepes, H., Poupinet, G., Fels, J.F., 2001. Seismological evidence on the geometry of the orogenic system in central-northern Ecuador (South America). Geophys. Res. Lett. 28, 3749-3752.

Gutscher, M.-A., Malavieille, J., Lallemand, S., Collot, J.-Y., 1999. Tectonic segmentation of the North Andean margin: impact of the Carnegie Ridge collision. Earth Planet. Sci. Lett. $168,255-270$.

Kelemen, P. B., Hanghøj, K., Greene, A.R., 2005. One View of the Geochemistry of Subductionrelated Magmatic Arcs, with an Emphasis on Primitive Andesite and Lower Crust. In: Rudnick, R.L. (Ed.), The Crust, vol. 3, Treatise on Geochemistry (eds. H.D. Holland and K. K. Turekian). Elsevier-Pergamon, Oxford, pp. 593-659.

Litherland, M., Aspden, J. A., 1992. Terrane-boundary reactivation: a control on the evolution of the Northern Andes. J. South Am. Earth Sci. 5: 71-76.

Litherland, M., Aspden, J.A., Jemielita, R.A., 1994. The metamorphic belts of Ecuador. British Geological Survey, Keyworth, U.K., Overseas Memoir 11, 147 p.

Lonsdale, P., 1978. Ecuadorian subduction system. AAPG Bull. 62(12), 2454-2477.

Mamberti, M., Lapierre, H., Bosch, D., Jaillard, E., Ethien, R., Hernandez, J., Polvé, M., 2003. Accreted fragments of the Late Cretaceous Caribbean-Colombian Plateau in Ecuador. Lithos 66, 173-199.

Martin, H., Moyen, J...F., Guitreau, M., Blichert-.-Toft, J., Le Pennec, J.-L., 2014. Why Archaean TTG cannot be generated by MORB melting in subduction zones. Lithos 198-199, 1-13.

Martinod, J., Guillaume, B., Espurt, N., Faccenna, C., Funiciello, F., Regard, V., 2013. Effect of aseismic ridge subduction on slab geometry and overriding plate deformation: Insights from analogue modeling. Tectonophysics 588, 39-55.

McArthur, J. M., Howarth, R. J., Bailey, T. R., 2001. Strontium Isotope Stratigraphy: LOWESS Version 3: Best Fit to the Marine Sr--Isotope Curve for 0-509 Ma and Accompanying Look"up Table for Deriving Numerical Age. The Journal of Geology 109, 155-"170.

Nair, R., Chacko, T., 2016. Role of oceanic plateaus in the initiation of subduction and origin of continental crust. Geology 36, 583-586. 
Patino, L.C., Carr, M.J., Feigenson, M.D., 2000. Local and regional variations in Central American arc lavas controlled by variations in subducted sediment input. Contrib. Mineral. Petrol. 138, 265-283.

Pin, C., Briot, D., Bassin, C., Poitrasson, F., 1994. Concomitant separation of strontium and samarium-neodymium for isotopic analysis in silicate samples, based on specific extraction chromatography. Analytica Chimica Acta 1994, 209-217.

Plank, T., 2005. Constraints from Thorium/Lanthanum on Sediment Recycling at Subduction Zones and the Evolution of the Continents. J. Pet. 46, 921-944.

Plank, T., Cooper, L. B., Manning, C. E., 2009. Emerging geothermometers for estimating slab surface temperatures. Nat. Geosci. 2, 611-615.

Rosenbaum, G., Giles, D., Saxon, M., Betts, P.G., Weinberg, R.F., Duboz, C., 2005. Subduction of the Nazca Ridge and the Inca Plateau: insights into the formation of ore deposits in Peru. Earth Planet. Sci. Lett. 239, 18-32.

Rudnick, R.L., Gao, S., 2005. Composition of the continental crust. In: Rudnick, R.L. (Ed.), The Crust, vol. 3, Treatise on Geochemistry (eds. H.D. Holland and K. K. Turekian). ElsevierPergamon, Oxford, pp. 1-65.

Sage, F., Collot, J.Y., Ranero, C.R., 2006. Interplate patchiness and subduction-"erosion mechanisms; evidence from depth-migrated seismic images at the central Ecuador convergent margin. Geology 34, 997-1000.

Sallarès, V., Charvis, P., Flueh, E. R., Bialas, J., THE SALIERI Scientific Party, 2005. Seismic structure of the Carnegie ridge and the nature of the Galápagos hotspot. Geophys. J. Int. $161,763-788$.

Samaniego, P., Robin, C., Ghazot, G., Bourdon, E., Cotton, J., 2010. Evolving metasomatic agent in the Northern Andean subduction zone, deduced from magma composition of the long-lived Pichincha volcanic complex (Ecuador). Contrib. Mineral. Petrol. 160, 239260.

Schiano, P., Monzier, M., Eissen, J.-P., Martin, H., Koga, K.T., 2010. Simple mixing as the major control of the evolution of volcanic suites in the Ecuadorian Andes. Contrib. Mineral. Petrol. 160, 297-312. 
Smithies, R.H., 2000. The Archaean tonalite-trondhjemite-granodiorite (TTG) series is not an analogue of Cenozoic adakite. Earth Planet. Sci. Lett. 182, 115-125.

Spikings, R.A., Winkler, W., Seward, D., Handler, R., 2001. Along-strike variations in the thermal and tectonic response of the continental Ecuadorian Andes to the collision with heterogeneous oceanic crust. Earth. Planet. Sci. Lett. 186, 57-73.

Spikings, R., Simpson, G., 2014. Rock uplift and exhumation of continental margins by the collision, accretion, and subduction of buoyant and topographically prominent oceanic crust. Tectonics $33,635-655$.

Tanaka, T., Togashi, S., Kamioka, H., Amakawa, H., Kagami, H., Hamamoto, T., Yuhara, M., Orihashi, Y., Yoneda, S., Shimizu, H., Kunimaru, T., Takahashi, K., Yanagi, Y., Nakano, T., Fujimaki, H., Shinjo, R., Asahara, Y., Tanimizu, M., Dragusanu, C., 2000. JNdi-1: a neodymium isotopic reference in consistency with La Jolla neodymium. Chemical Geology 168, 279-281.

Tang, M., Lee, C.-T. A., Chen, K., Erdman, M., Costin, G., Jiang, H., 2019. Nb/Ta systematics in arc magma differentiation and the role of arclogites in continent formation. Nat. Comm. $10,235$.

Turner, S. J., Langmuir, C. H., 2015. What processes control the chemical compositions of arc front stratovolcanoes? Geochem. Geophys. Geosyst. 16, 1865-1893.

Turner, S.J., Langmuir, C.H., Katz, R.F., Dungan, M.A., Escrig, S., 2016. Parental arc magma compositions dominantly controlled by mantle-wedge thermal structure. Nat. Geosci. 9, $772 \cdots 776$.

Vallejo, C., Winkler, W., Spikings, R.A., Luzieux, L., Heller, F., Bussy, F., 2009. Mode and timing of terrane accretion in the forearc of the Andes in Ecuador. In: Kay, S.M., Ramos, V.A., Dickinson, W.R. (Eds.), Backbone of the Americas: Shallow Subduction, Plateau Uplift, and Ridge and Terrane Collision. Geological Society of America Memoir 204, doi:10.1130/2009.1204(09). 


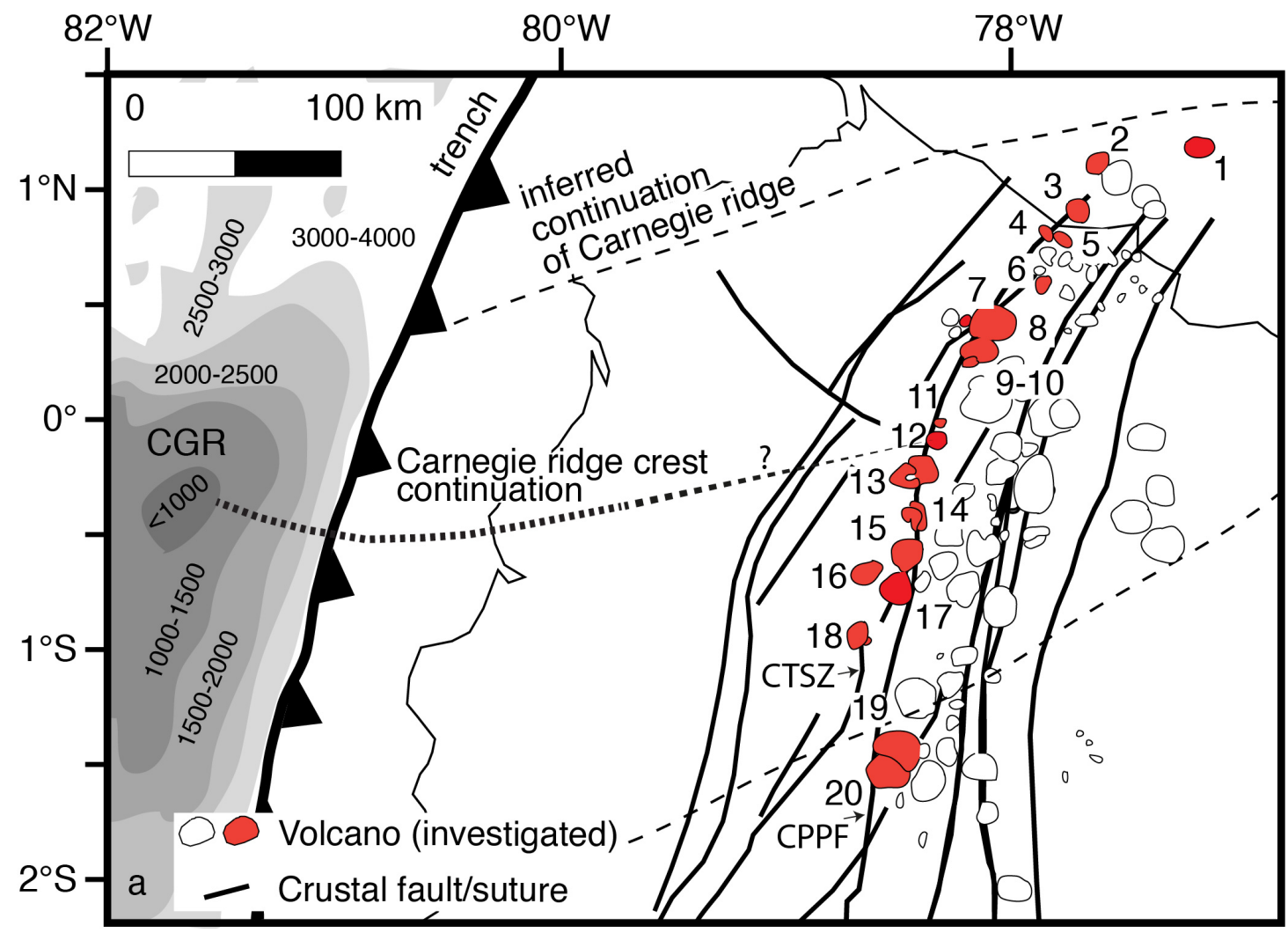

Figure 1 
UNITS

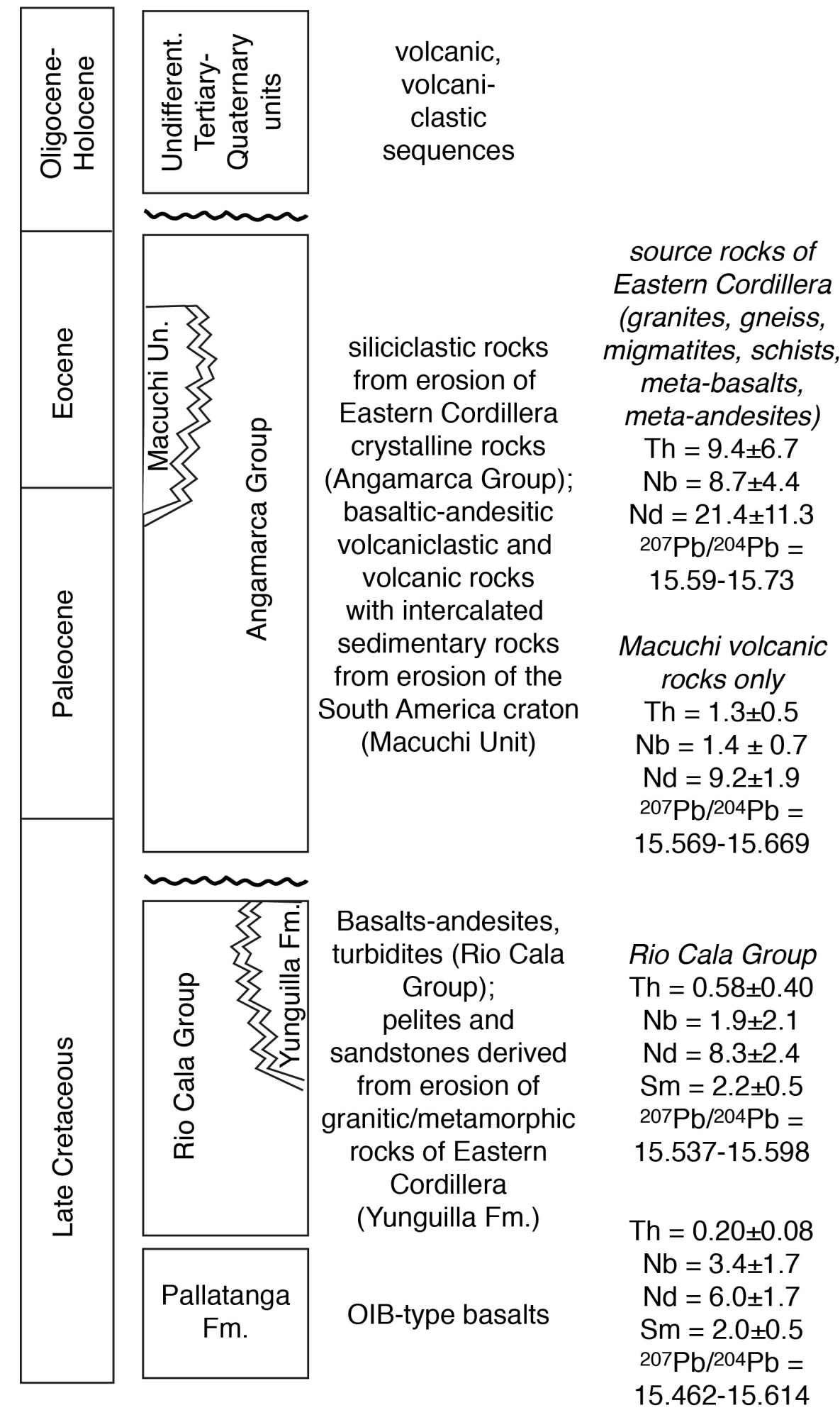

Figure 2 

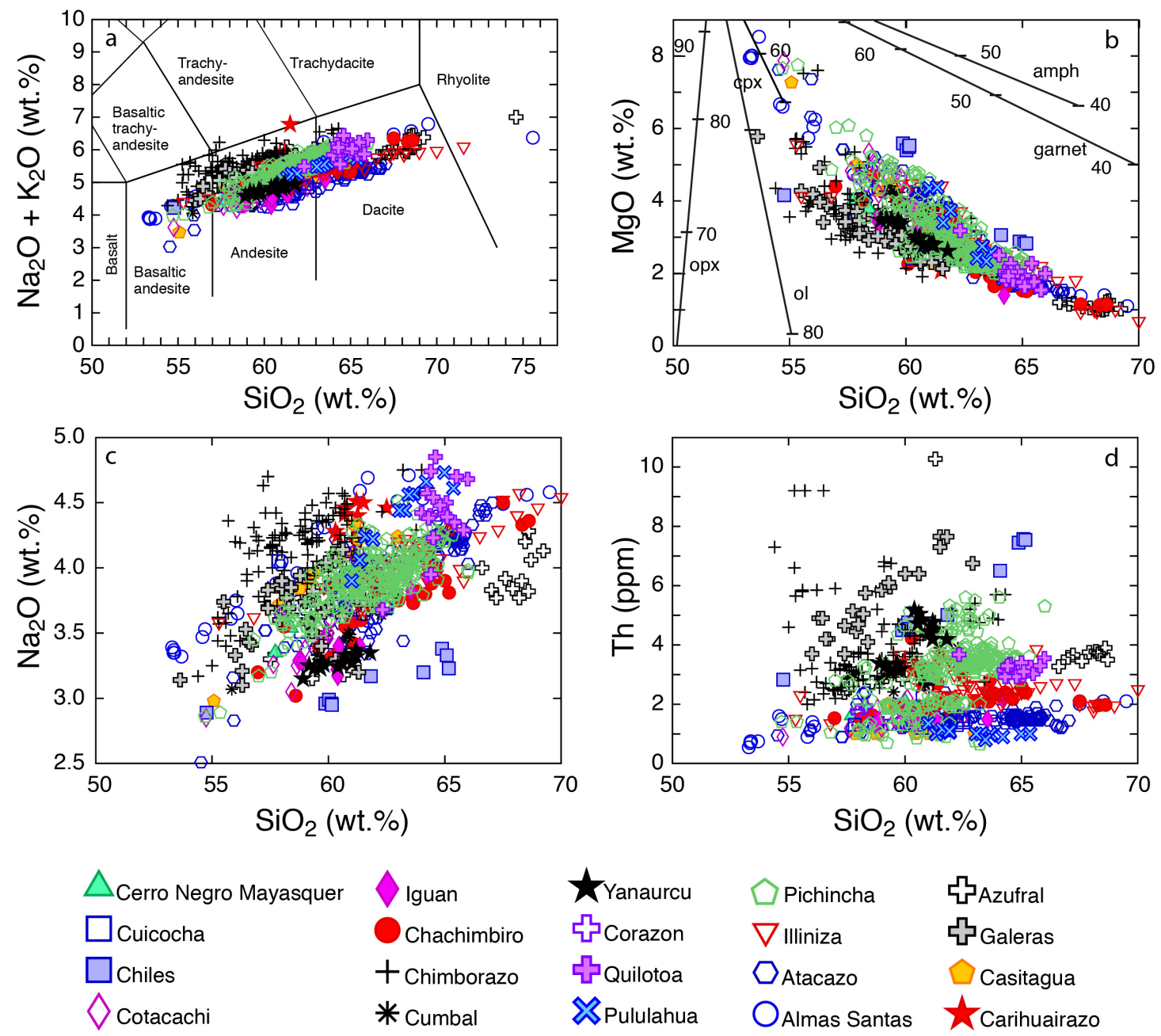

Figure 3 

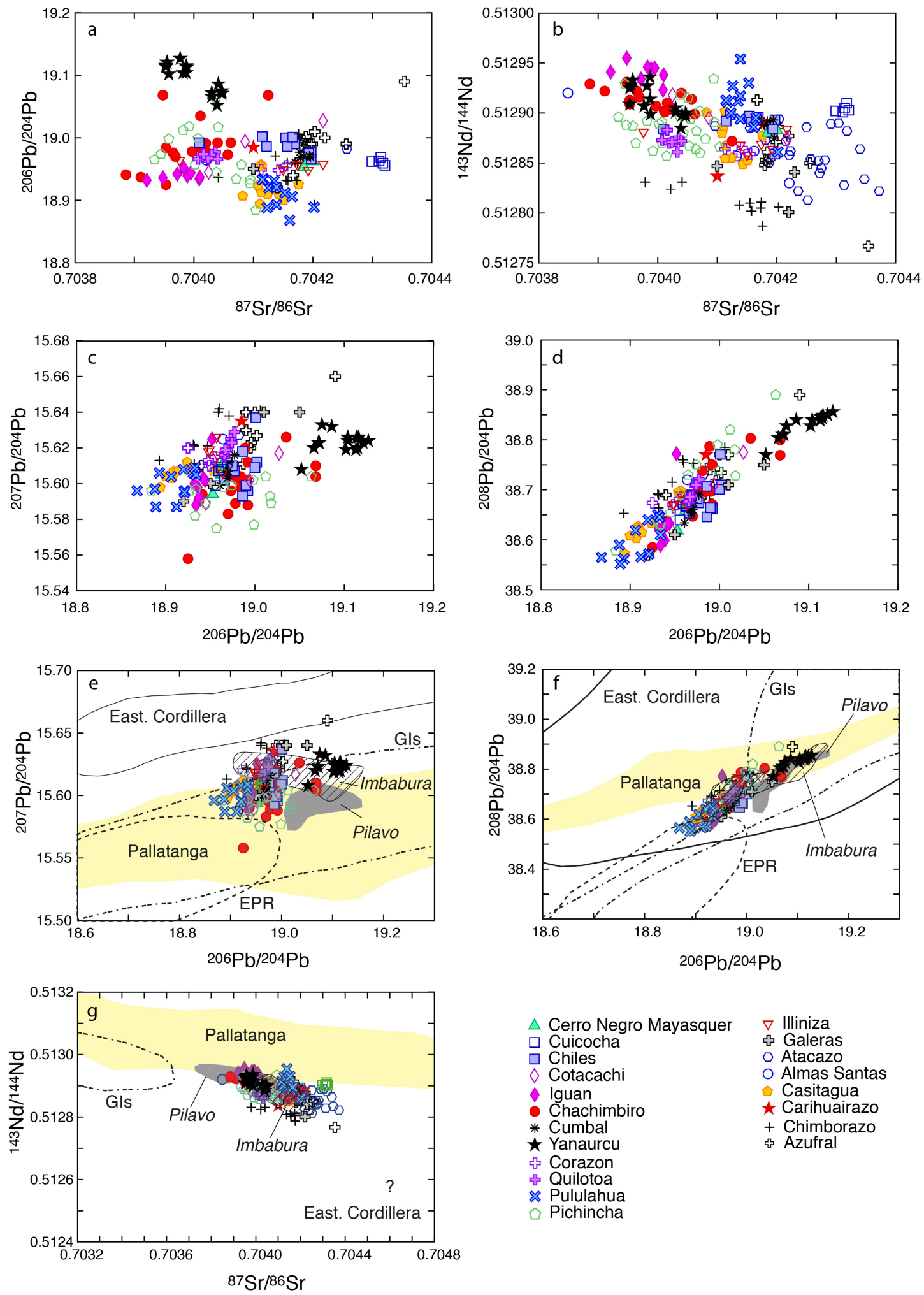

$\triangle$ Cerro Negro Mayasquer
$\square$ Cuicocha
$\square$ Chiles
$\diamond$ Cotacachi
Iguan
Chachimbiro
$*$ Cumbal
$\star$ Yanaurcu
\& Corazon
Quilotoa
$\ltimes$ Pululahua
$\square$ Pichincha

$\nabla$ Illiniza

↔ Galeras

- Atacazo

- Almas Santas

- Casitagua

• Carihuairazo

+ Chimborazo

Azufral

$\checkmark$ Pichincha

Figure 4 

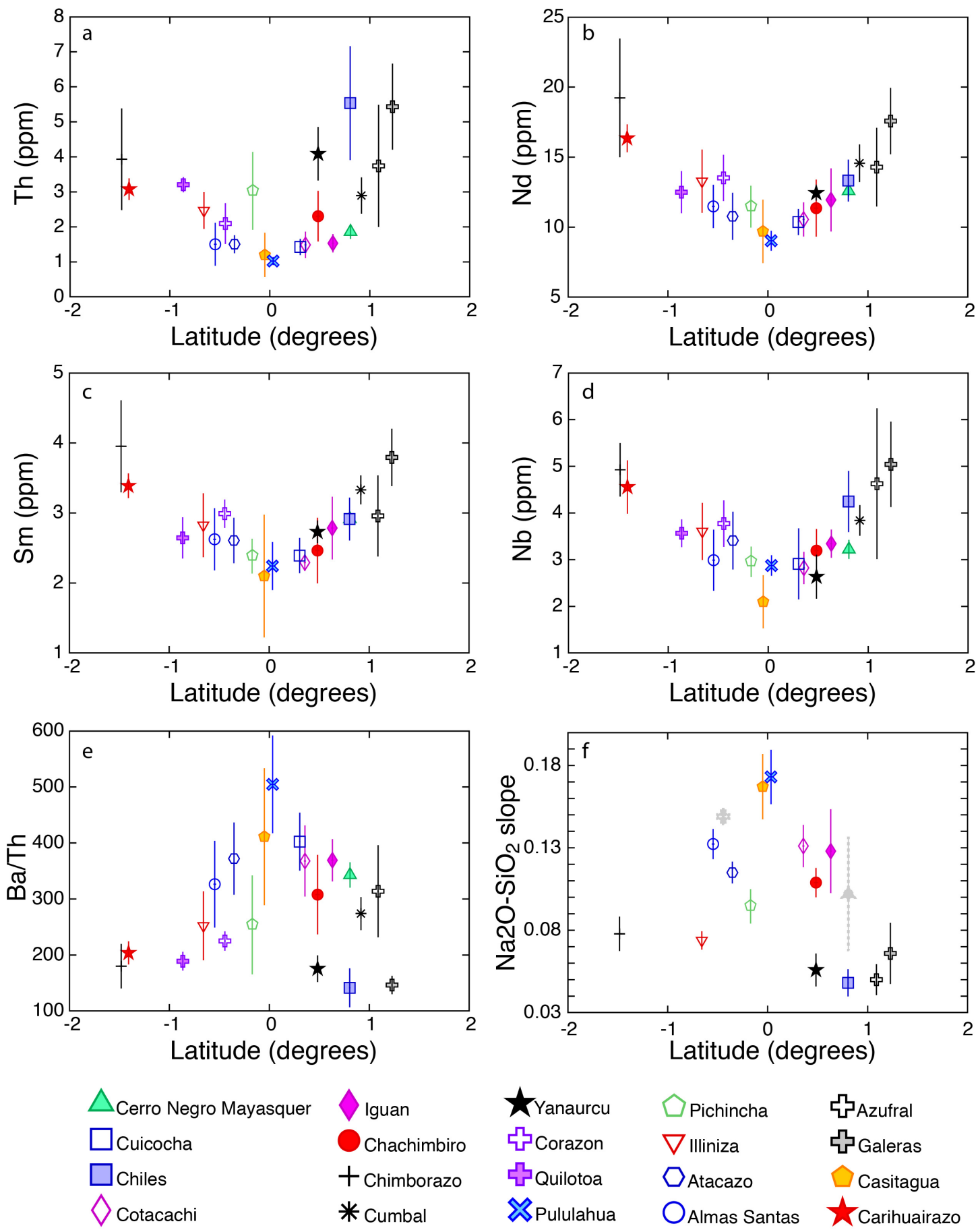

Figure 5 

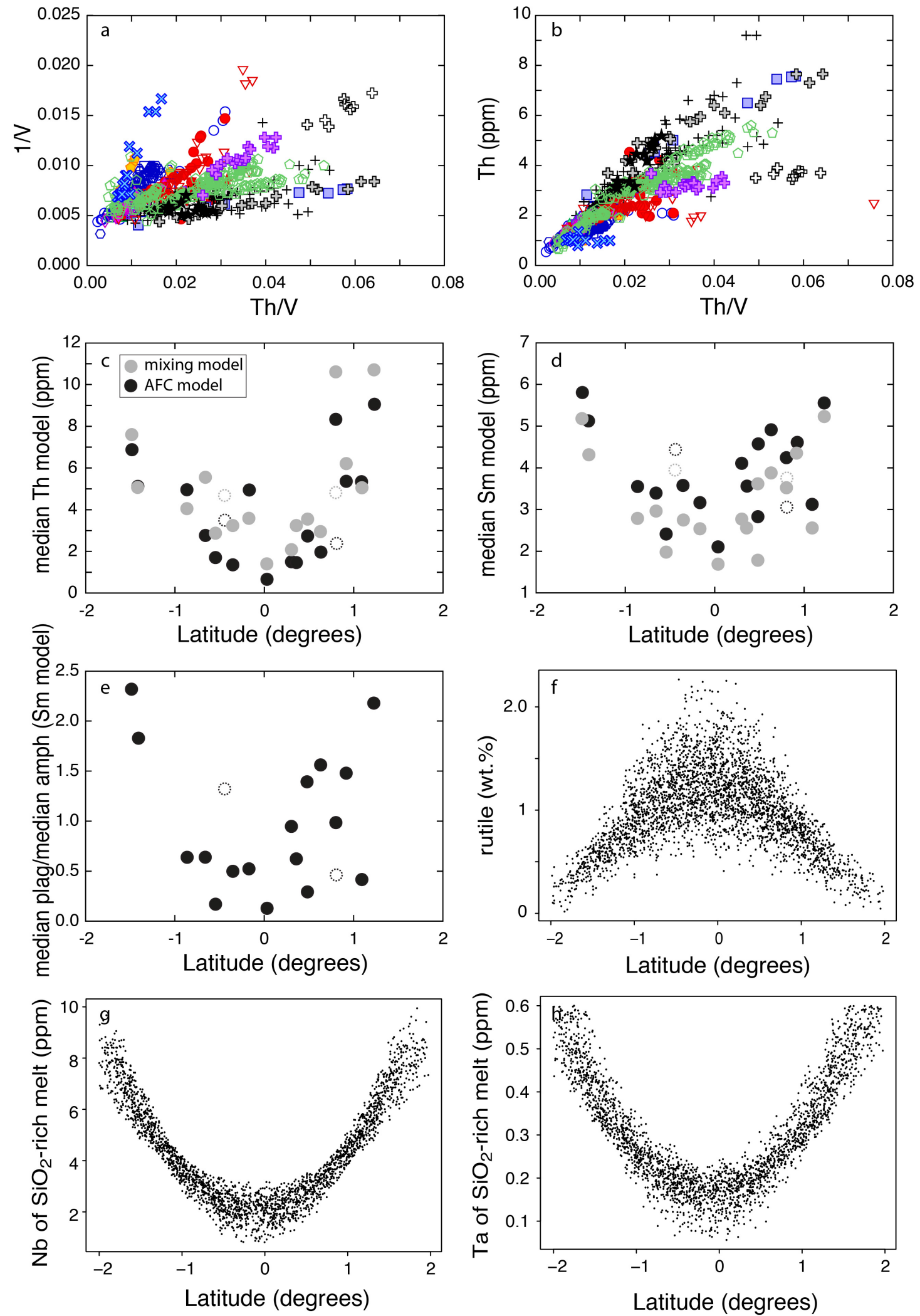

Figure 6 

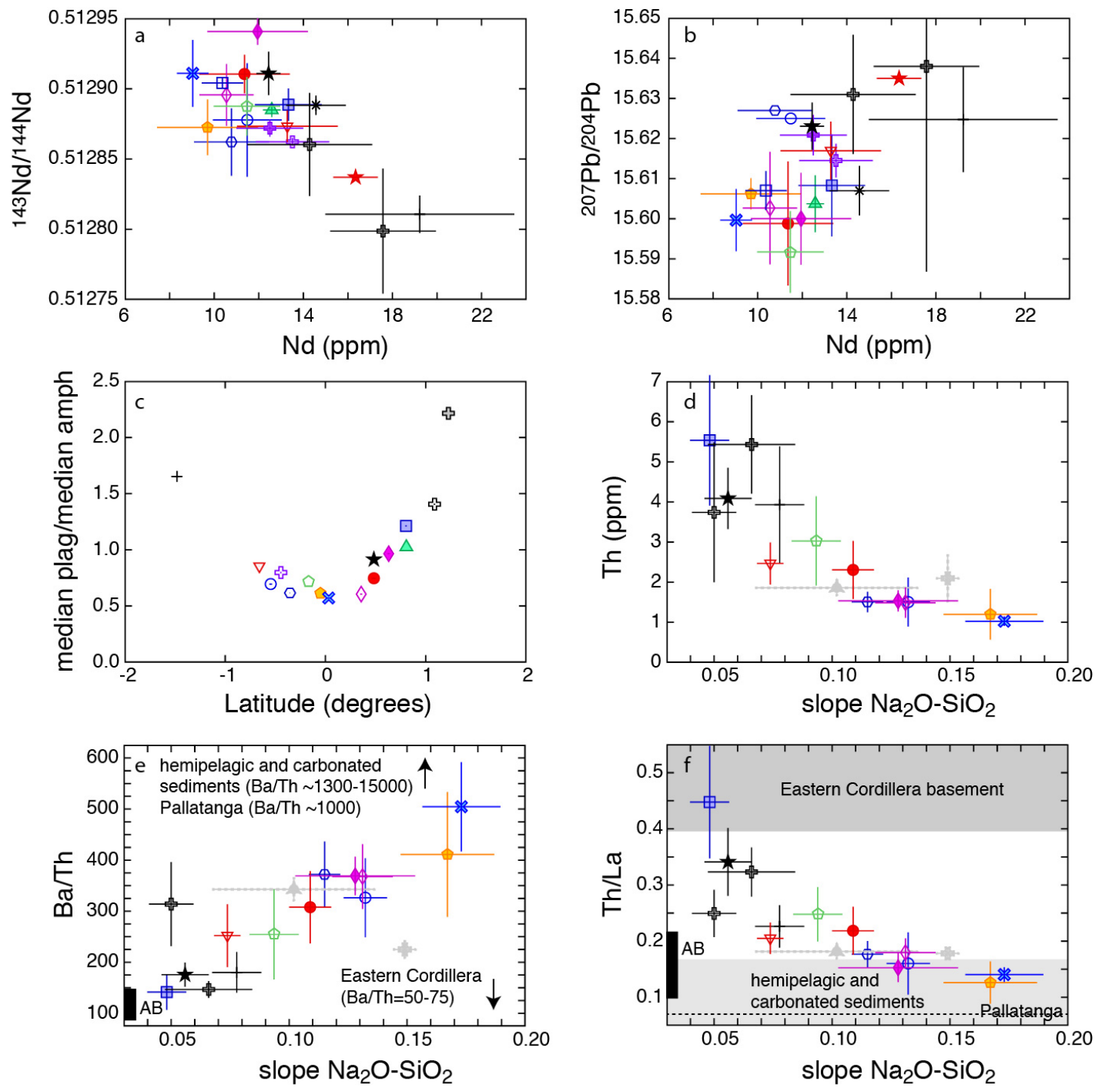

Figure 7 


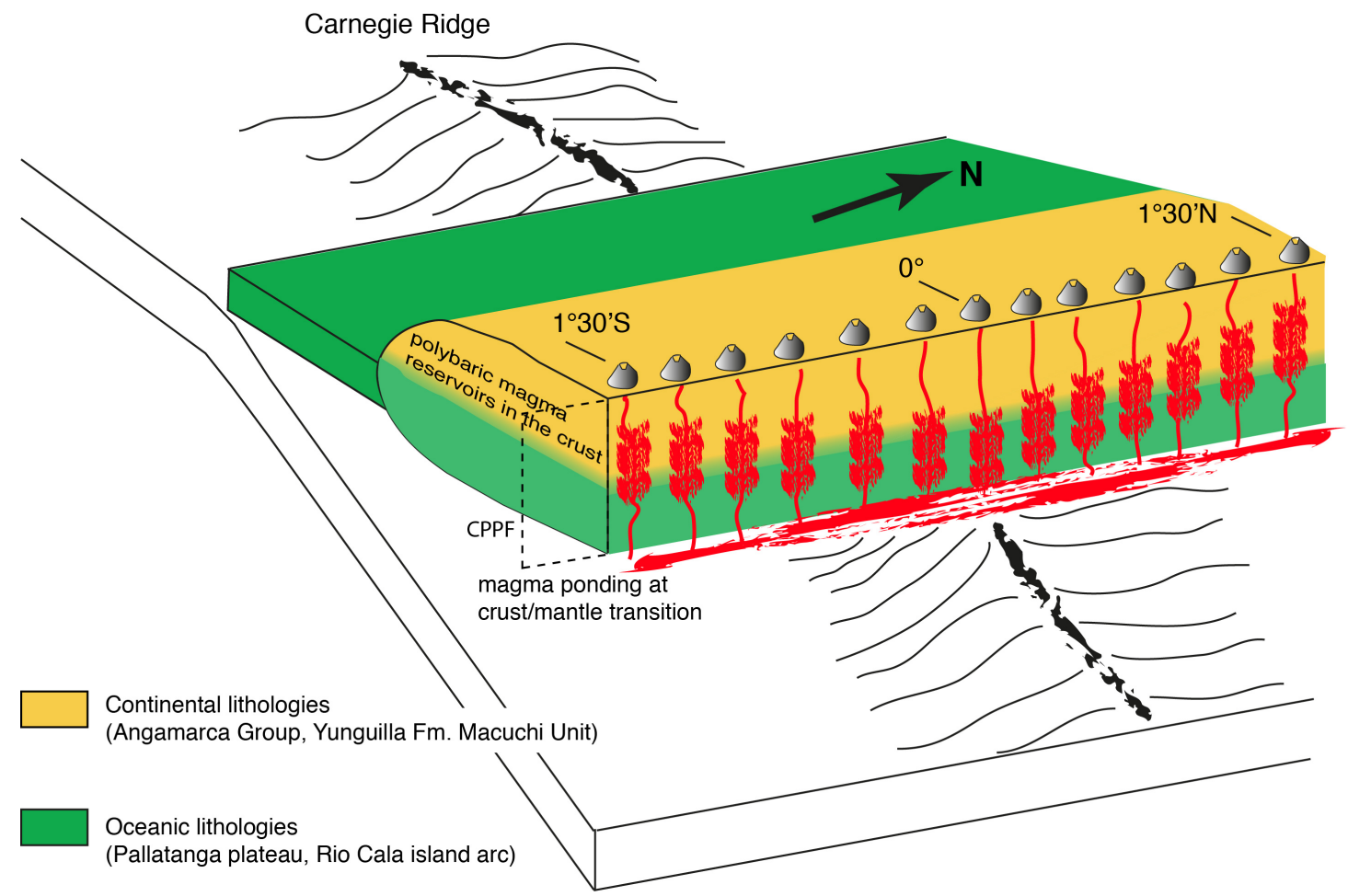

Figure 8 


\title{
Supplementary Material
}

\section{Effects of aseismic ridge subduction on geochemistry of frontal arc magmas}

\author{
Massimo Chiaradia ${ }^{*}$, Othmar Müntener ${ }^{2}$, Bernardo Beate ${ }^{3}$ \\ ${ }^{1}$ Department of Earth Sciences, University of Geneva, Rue des Maraîchers 13, 1205 \\ Geneva, Switzerland \\ ${ }^{2}$ Institute of Earth Sciences, University of Lausanne, 1015 Lausanne, Switzerland \\ ${ }^{3}$ Department of Geology, Escuela Politecnica Naciónal, Quito, Ecuador \\ * corresponding author: Massimo.Chiaradia@unige.ch
}



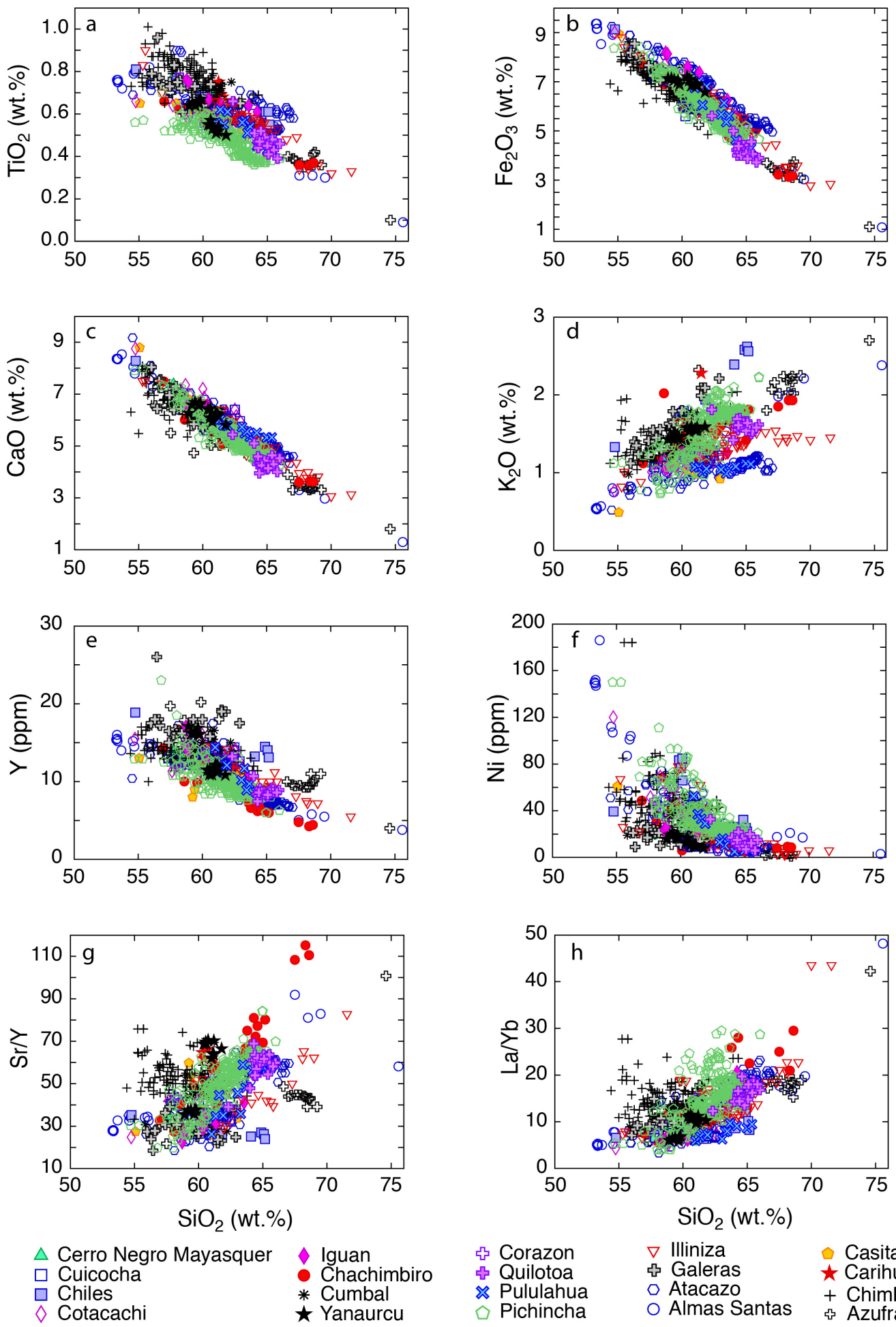

↔ Corazon
Quilotoa
$\rtimes$ Pululahua
$\square$ Pichincha

$\nabla$ Illiniza

њ Galeras

- Atacazo

$\diamond$ Cotacachi

* Cumbal

O Almas Santas

- Casitagua

\& Azufral

Figure S1: Major and trace element plots of volcanic rocks of the investigated volcanoes (data are from this study, Samaniego et al., 2010, Ancellin et al., 2017, and the Georoc database: http://georoc.mpch-mainz.gwdg.de/georoc/). 

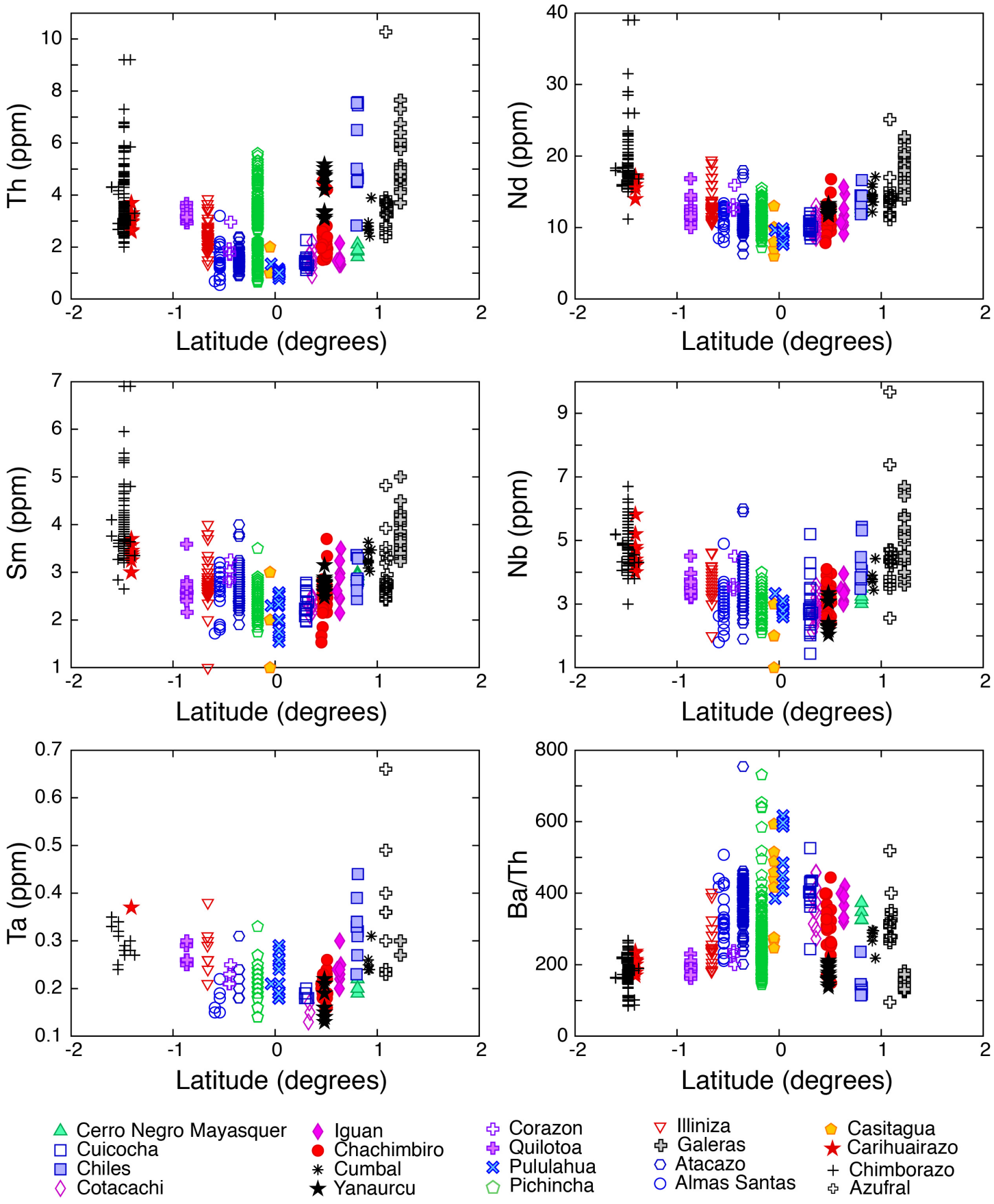

O Almas Santas \& Azufral

Figure S2: Latitudinal variations of geochemical parameters of rocks of the investigated volcanoes. 

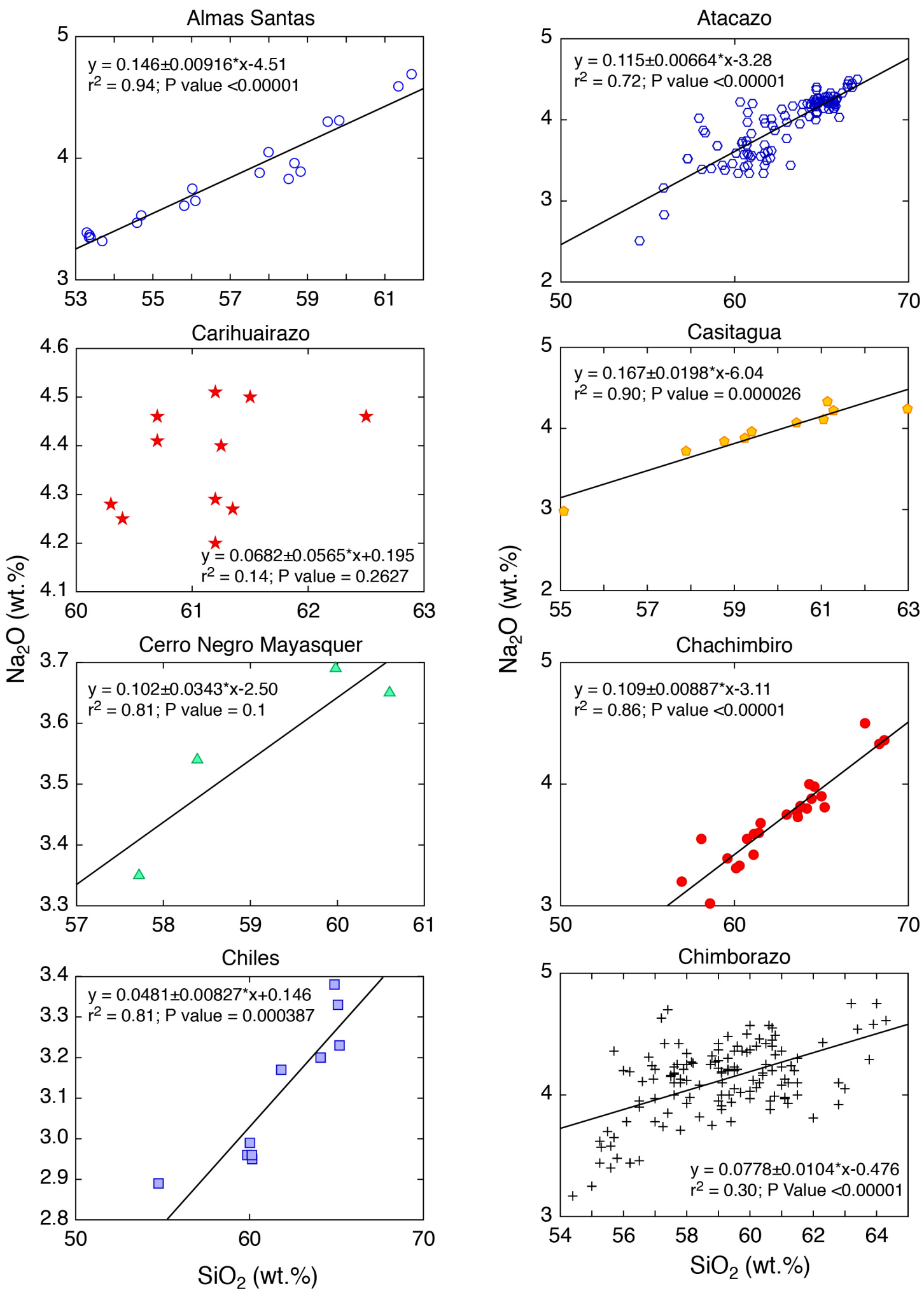

Figure S3: Correlations between $\mathrm{Na}_{2} \mathrm{O}-\mathrm{SiO}_{2}$ for rocks of the 20 volcanoes investigated in this study. For some volcanoes high $\mathrm{SiO}_{2}$ rocks were excluded from the regression because they showed a kinked change in the slope of the correlation, suggesting the onset of significant fractionation of albitic plagioclase in the late stage of magma evolution. Volcanoes for which no regression line is drawn gave either statistically weak regressions, or statistically acceptable regressions controlled by 1 point, and were not considered. 

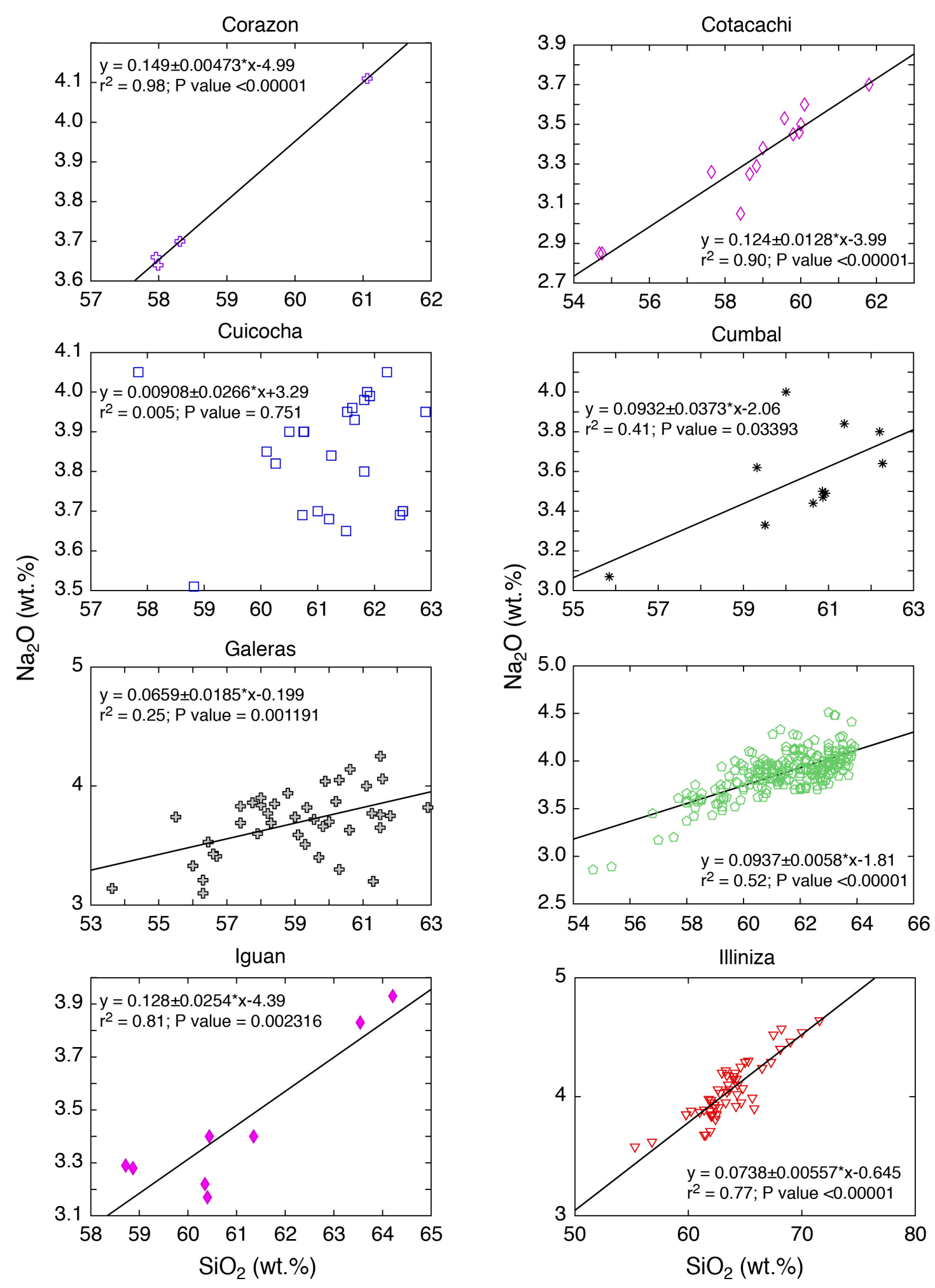

Figure S3 continued 

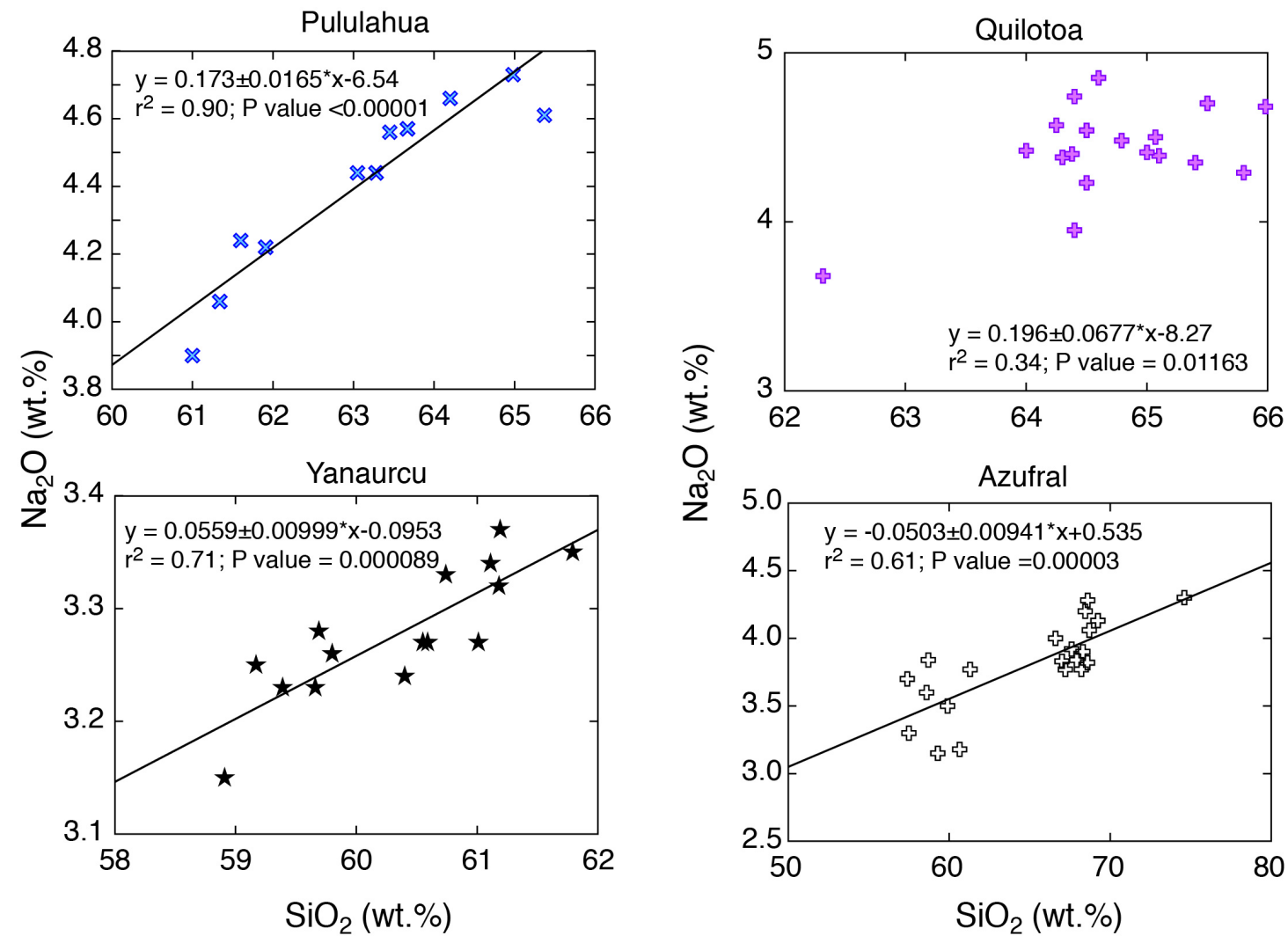

Figure S3 continued 

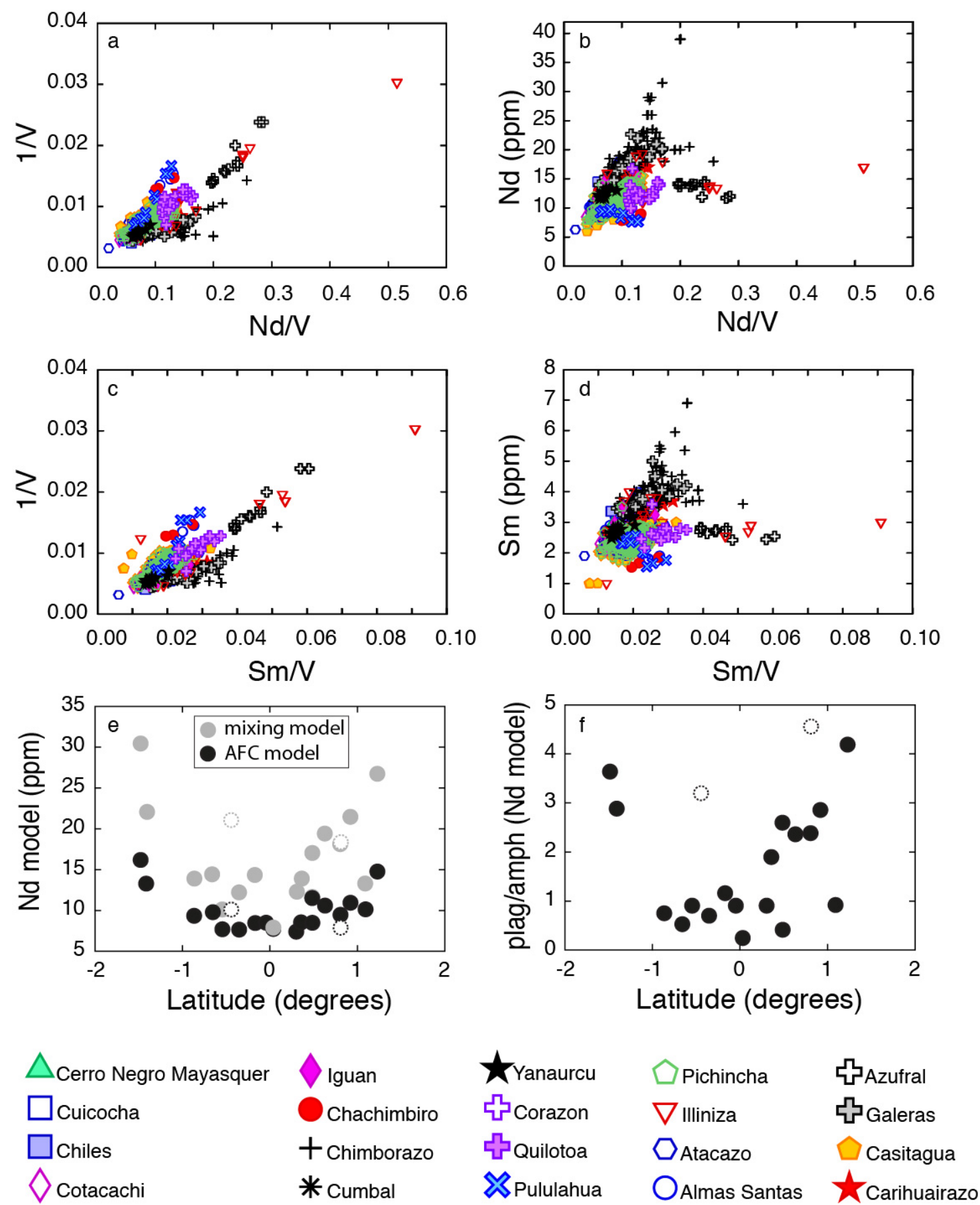

Figure S4: (a-d) 1/V-Nd/V, Nd-Nd/V, 1/V-Sm/V, and Sm-Sm/V trends defined by the frontal arc volcanoes; (e) Nd contents of the assimilant in the AFC model (colored symbol) and of the mixed melt in the mixing model (greyed symbols) needed to explain the trends in the plots of Figs. S4a-d; (f) changes in the ratio of fractionating plagioclase and amphibole in the AFC model needed to explain the different trends defined by the volcanoes in the $1 / V-N d / V$ and $N d-N d / V$ space. In Figs. $S 4$-f Cerro Negro and Corazon have no color fillings to highlight the fact that the regressions for these 2 volcanoes are based on only 4 samples. 


\section{Monte Carlo modelling}

Modelling of the trends in the $1 / V-(T h, N d, S m) / V$ and $(T h, N d, S m)-(T h, N d, S m) / V$ spaces by $A F C$ and pure mixing processes

We have modelled the linear trends in the $1 / \mathrm{V}-(\mathrm{Th}, \mathrm{Nd}, \mathrm{Sm}) / \mathrm{V}$ spaces and the curved trends in the (Th, Nd, Sm)-(Th, Nd, Sm)/V spaces reproducing them both by AFC (DePaolo, 1981) and pure mixing equations (Figure S4). In both cases the Th, Nd, Sm and V contents of the parent (AFC) or more primitive (mixing) magma were determined graphically by the common origin of the trends in the (Th, Nd, Sm)-V spaces (Figures 7a-b and S3; Table S1).
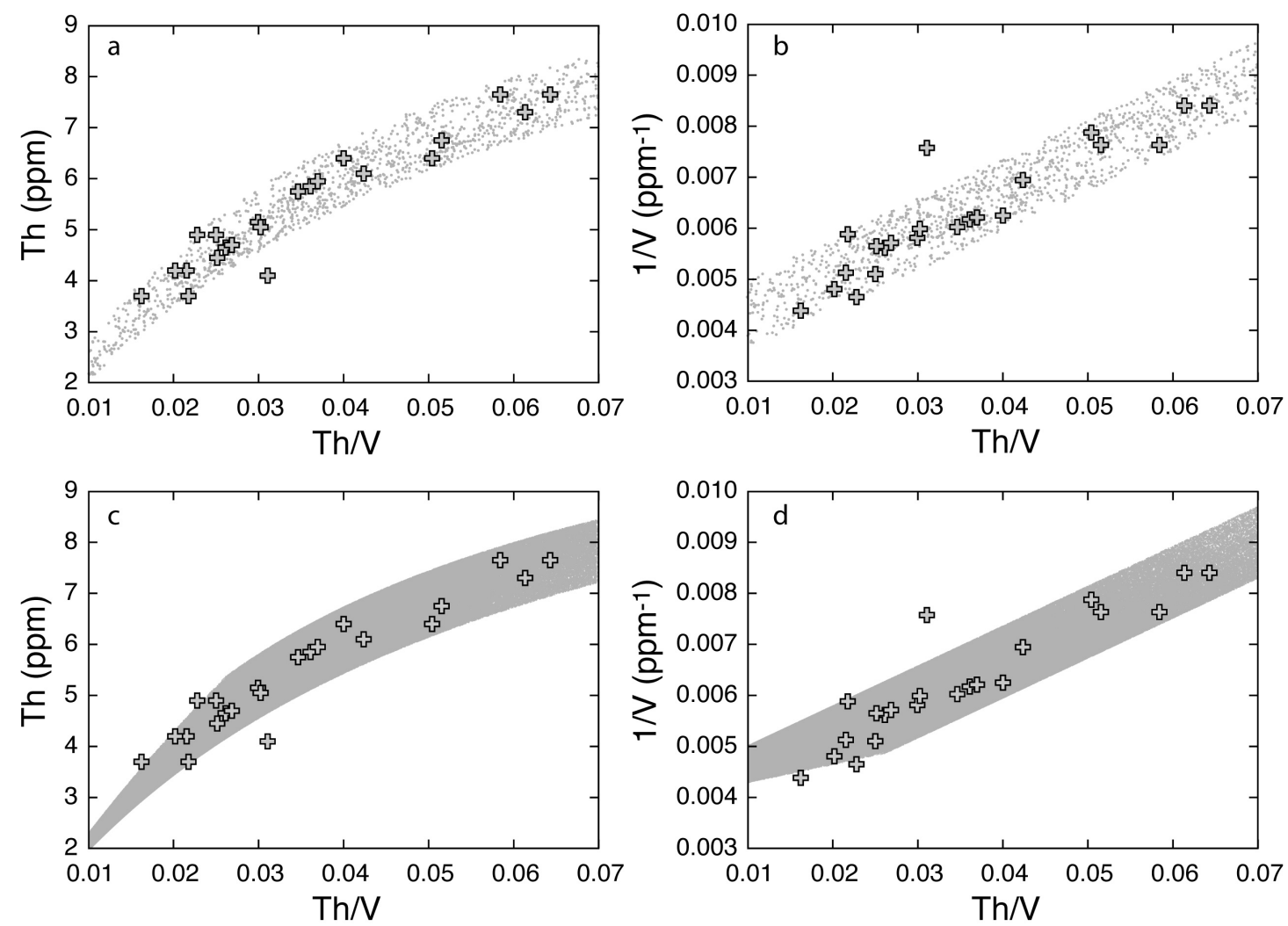

Figure S5: Monte Carlo simulations of $\operatorname{AFC}(a, b)$ and mixing $(c, d)$ processes to explain the correlated trends occurring at each volcano in the space Th-Th/V and $1 / V-T h / V$ (Galeras volcano is used as an example). Grey points are successful simulations constrained to fit the curved an dlinear trends through linear and exponential equations.

In the AFC model we have allowed fractionation of plagioclase, clinopyroxene, orthopyroxene, and amphibole (each one within a range between 0 and $60 \%$ ) as well as minor amounts of magnetite (1-2\%) and apatite $(0-0.5 \%)$. We have allowed fractionation between 30 and $60 \%$ and an $\mathrm{r}$ parameter (assimilation/crystallization) ranging between 0.2 and 0.8 . For each mineral we have compiled all the available partition coefficients between minerals and calcalkaline silicate melts (GERM database) and let the simulations (3'000'000 for AFC and 1'000'000 for mixing) run for ranges of KDs between the $20^{\text {th }}$ and $80^{\text {th }}$ percentile of the values compiled (Table S2). Also the Th, Nd, Sm, V contents of the assimilant (AFC) and of the mixed magma (mixing) were allowed to range 
within a broad range of values (Table S1) for the 3'000'000 (AFC) and 1'000'000 (mixing) simulations. At the end only the successful simulations reproducing the trends in all plots within an uncertainty of $\pm 20 \%$ were retained (Figure S4). The model returned Th, Nd, Sm, $\mathrm{V}$ contents of the assimilant or mixed magma as populations of values with a normal distribution, out of which the median values were calculated and plotted in Figures 5 and S3. Simulations were run using an in-house code written in RStudio.

Table S1: V, Th, Nd, and Sm contents (ppm) of reservoirs used for the modelling.

$\begin{array}{llll} & \begin{array}{l}\text { Parent (AFC)/ } \\ \text { primitive (mixing) }\end{array} & \text { Assimilant (AFC) } & \text { Mixed (mixing) } \\ & & & \\ \mathrm{V} & 250 & 60-330 & 20-120 \\ \mathrm{Th} & 0.5 & 0.2-18 & 0.2-15 \\ \mathrm{Nd} & 8.8 & 6-30 & 5-50 \\ \mathrm{Sm} & 2.3 & 1.8-10 & 0.1-10\end{array}$

Table S2: Partition coefficients ranges of $V$, Th, Nd, and Sm used for modelling. Ranges are the $20^{\text {th }}$ and $80^{\text {th }}$ percentiles of the values retrieved from the GERM database for minerals/calc-alkaline silicate melts.

$\begin{array}{lllllll} & \text { Plag } & \text { Cpx } & \text { Opx } & \text { Amph } & \text { Ap } & \text { Mt } \\ \text { V } & 0.024- & 0.9-4.82 & 0.5-2.2 & 2.536- & 0-0 & 7.22-48.4 \\ & 0.236 & & & 6.024 & & \\ \text { Th } & 0.01-0.13 & 0.007-0.06 & 0-0 & 0.06-0.23 & 17-18 & 0.05-0.27 \\ \text { Nd } & 0.03-0.21 & 0.129- & 0-0 & 0.32-1.214 & 18-68 & 0.09-0.451 \\ & & 0.694 & & & & \\ \text { Sm } & 0.036-0.14 & 0.292- & 0-0 & 0.776- & 8.6-40.2 & 0.044-0.45 \\ & & 0.9824 & & 2.316 & & \end{array}$


We have modelled the latitudinal variations of $\mathrm{Nb}$ and $\mathrm{Ta}$ average values of frontal volcanoes of Ecuador (Figure 5 and Figure S5) by AFC (DePaolo, 1981) and pure mixing equations. The $\mathrm{Nb}$ and $\mathrm{Ta}$ values of the parent (AFC) and primitive (mixing) magma are reported in Table S3.
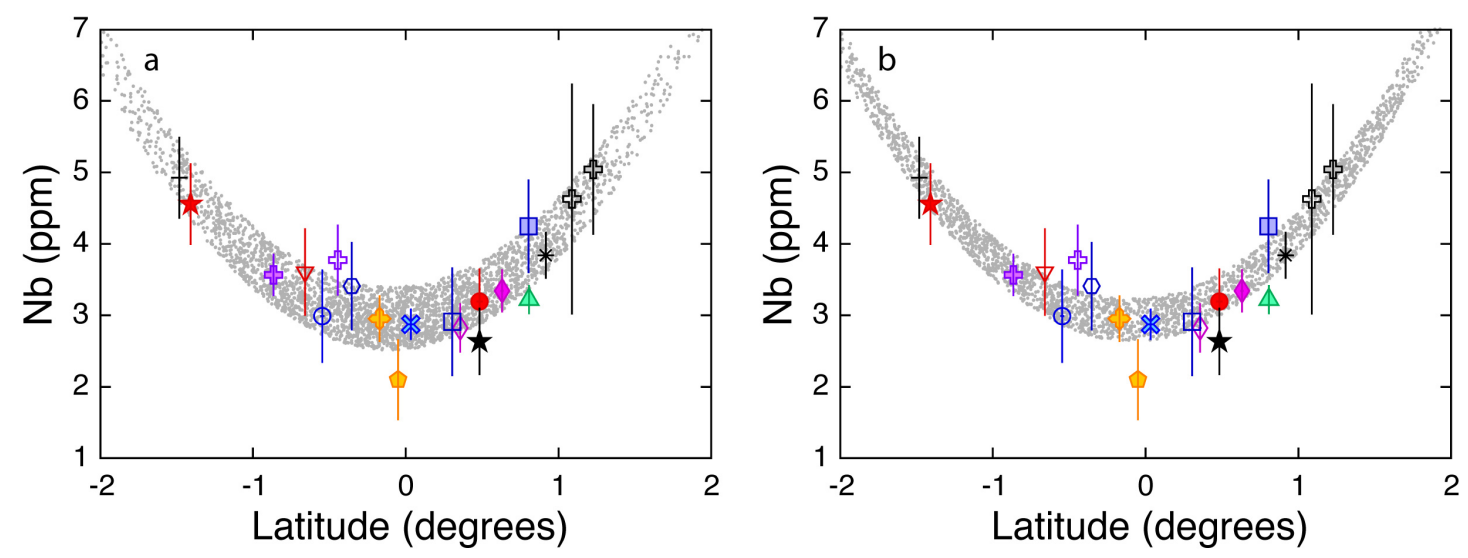

Figure S6: Monte Carlo simulations of AFC (a) and mixing (b) processes to explain the latitudinal symmetric variations in $\mathrm{Nb}$ and $\mathrm{Ta}$ (not shown). Grey points are successful simulations constrained to fit the latitudinal variation of $\mathrm{Nb}$ through a polynomial equation.

In the AFC model we have allowed fractionation of plagioclase, clinopyroxene, orthopyroxene, and amphibole (between 0 and $80 \%$ ) as well as minor amounts of titanite $(0.01-5 \%)$ and rutile $(0.01-5 \%)$. For each mineral we have compiled all the available partition coefficients between minerals and calc-alkaline silicate melts (GERM database) and let the simulations (2'000'000 for AFC) run for ranges of KDs between the $20^{\text {th }}$ and $80^{\text {th }}$ percentile of the values compiled (Table S4). Also the $\mathrm{Nb}$ and $\mathrm{Ta}$ contents of the assimilant (AFC) and of the mixed magma (mixing) were allowed to range within a range of values (Table S3) for the 2'000'000 (AFC) and 1'000'000 (mixing) simulations. At the end only the successful simulations reproducing the trends in all plots within an uncertainty of $\pm 15 \%$ were retained (Figure S5). The model returned $\mathrm{Nb}$ and Ta contents of the assimilant or mixed magma as well as \% of fractionating minerals (AFC) which are plotted in Figure 6. Simulations were run using an in-house code written in RStudio.

Table S3: Nb and Ta contents (ppm) of reservoirs used for the modelling.

$\begin{array}{lllll} & \text { Parent }(A F C) & \begin{array}{l}\text { Primitive } \\ \text { (mixing) }\end{array} & \text { Assimilant }(A F C) & \text { Mixed (mixing) } \\ \mathrm{Nb} & 5-6 & 4 & 5-12 & 0.5-10 \\ \mathrm{Ta} & 0.3-0.4 & 0.2-0.3 & 0.6-0.9 & 0.05-0.6\end{array}$


Table S4: Partition coefficients ranges of $\mathrm{Nb}$ and Ta used for modelling. Ranges are the $20^{\text {th }}$ and $80^{\text {th }}$ percentiles of the values retrieved from the GERM database for minerals/calc-alkaline silicate melts.

$\begin{array}{lllllll} & \text { Plag } & \text { Cpx } & \text { Opx } & \text { Amph } & \text { Tit } & \text { Rut } \\ \mathrm{Nb} & 0.001-0.14 & 0.001-0.2 & 0-0 & 0.2-0.8 & 3-8 & 106-136 \\ \mathrm{Ta} & 0.01-0.17 & 0.03-0.52 & 0-0 & 0.2-1 & 10-142 & 5-195\end{array}$


Modelling of the linear correlations in the $\mathrm{Na}_{2} \mathrm{O}-\mathrm{SiO}_{2}, \mathrm{Al}_{2} \mathrm{O}_{3}-\mathrm{SiO}_{2}, \mathrm{MgO}-\mathrm{SiO}_{2}, \mathrm{CaO}$ $\mathrm{SiO}_{2}$ spaces

Each volcano displays linear trends with distinct slopes in the $\mathrm{Na}_{2} \mathrm{O}-\mathrm{SiO}_{2}$ space (Figure S2). Additionally volcanoes also display correlated trends in the $\mathrm{Al}_{2} \mathrm{O}_{3}$ $\mathrm{SiO}_{2}, \mathrm{MgO}-\mathrm{SiO}_{2}$, and $\mathrm{CaO}-\mathrm{SiO}_{2}$ spaces. We have modelled for each volcano all the correlated trends in the above spaces simultaneously as they were produced by pure fractional crystallization of the main mineralogical phases observed in petrographic thin sections, namely plagioclase, clinopyroxene, amphibole, and spinel. For the volcanoes showing a visible change in the slopes of regressions at high $\mathrm{SiO}_{2}$ values (indicating the onset of fractionation of different minerals or different mineral proportions), we have excluded the most $\mathrm{SiO}_{2}$-rich samples from the regressions. As parent magmas we choose the least evolved sample of each volcano and allowed $a \pm 1 \%$ to $\pm 10 \%$ variation around this value (depending on the element) in the Monte Carlo simulations. We carried out $6^{\prime} 000^{\prime} 000$ simulations to find out the combination of fractionating minerals that fitted within $5 \%$ of uncertainty the "liquid lines of descent" represented by the correlated trends in the multidimensional $\mathrm{SiO}_{2}-\mathrm{Na}_{2} \mathrm{O}-\mathrm{MgO}-\mathrm{Al}_{2} \mathrm{O}_{3}-\mathrm{CaO}$ space.

The amounts of each individual fractionating mineral were returned as populations of possible values in the overall simulations, with a normal or near normal distribution. From these populations the median values were taken and are reported in Figures $6 \mathrm{c}$ and S3 as plagioclase/amphibole ratios. Simulations were run using an in-house code written in RStudio.

Mineral compositions of fractionating plagioclase, clinopyroxene, amphibole were taken from representative Ecuadorian volcanic samples from the database of the senior author (Table S5).

Table S5: Mineral compositions of fractionating plagioclase, clinopyroxene, amphibole taken from representative Ecuadorian volcanic samples.

$\begin{array}{lllll} & \text { Plagioclase } & \text { Clinopyroxene } & \text { Amphibole } & \text { Spinel } \\ \mathrm{SiO}_{2} & 49.76 & 49.71 & 42.4 & 0.03 \\ \mathrm{TiO}_{2} & 00.016 & 0.59 & 1.29 & 1.062 \\ \mathrm{Al}_{2} \mathrm{O}_{3} & 31.56 & 4.69 & 13.15 & 11.90 \\ \mathrm{Cr}_{2} \mathrm{O}_{3} & 0.01 & 0.05 & 0.01 & 0.10 \\ \mathrm{FeO} & 0.66 & 9.75 & 12.87 & 69.43 \\ \mathrm{MnO} & 0.18 & 0.43 & 0.20 & 0.389 \\ \mathrm{MgO} & 0.05 & 13.38 & 13.49 & 12.24 \\ \mathrm{CaO} & 14.46 & 20.89 & 11.13 & 0 \\ \mathrm{Na} 2 \mathrm{O} & 2.78 & 0.46 & 2.44 & 0 \\ \mathrm{NiO} & 0 & 0.01 & 0.02 & 0.12 \\ \mathrm{~K} 2 \mathrm{O} & 0.17 & 0.02 & 0.45 & 0 \\ \mathrm{P}_{2} \mathrm{O} & 0 & 0 & 0 & 0\end{array}$

